\title{
Tasavvuf Sanat İlişkisi Bağlamında Şeyh Safiyyüddîn Dergâhı
}

\author{
Ayșe Ersay Yüksel*
}

\section{Öz}

Şeyh Safiyyüddîn, tarikatının merkezini Erdebil'de kurmuş ve mühim bir mensup kitlesine sahip olmuş bir mutasavvıftır. Onun vefatının ardından defnedildiği Şeyh Safiyyüddîn türbesi ve dergâhı, Safevî mimarisi ve sanatının en görkemli eserlerinin ortaya çıkmasına vesile olmuş önemli bir yapılar bütünüdür. Safevîyye tarikatı bu bağlamda sadece mistik bir akım ve dini düşünce sistemi olmaktan ziyade incelenmeye değer bir kültürel oluşum nüvesidir. Safevîlerin tarihi boyunca gelişim ve değişim yaşayan bu tarikatın şeyh ve şahların ortaklı̆̆ında yürütülen idaresi Şeyh Safiyyüddîn Dergâhının törensel ve mimari düzenlerinde de görünür kılınmaya çalışılmıştır. Bu araştırmanın konusunu oluşturan tasavvuf ve sanat ilişkisi bağlamında ortaya çıkan ve gelişen Şeyh Safi Türbesi ve Dergâhı şimdiye değin dini, sosyal ve siyasi açılardan incelenmiş olup bu dergâhın devrin ve sonrası dönemlerin sanat ortamına yansımaları yeterince değerlendirilmemiştir. Bu makalenin temel hedefi Şeyh Safiyyüddîn Türbe ve Dergâhının Safevi tarihi boyunca yapılaşma süreci ile gördüğü himayeyi mimari yapılar bağlamında değerlendirmektir. Ayrıca makalede Şeyh Safiyyüddîn Dergâhı kapsamında Safevîlerin inançsal kodlarını sanatsal köken aracılı̆̆ıyla nasıl aktardığını ortaya koymak hedeflenmiştir.

Anahtar Kelimeler: İslam Sanatları Tarihi, Şeyh Safiyyüddîn, Şeyh Safiyyüddîn Türbesi ve Dergâh1, Erdebil, Çinihâne, Sanat Himayesi

Arş. Gör. Dr., Çukurova Üniversitesi İlahiyat Fakültesi, Türk İslam Sanatları Tarihi Ana Bilim Dal1, ayseersay@hotmail.com, ORCID: 0000-0002-0314-6182. 


\title{
Sheikh Safi Al-Din Khanegah And Shrine in The Context of Sûfîsm Art Relationship
}

Ayşe Ersay Yüksel*

\begin{abstract}
Sheikh Safi al-Din is a mystic Islamic scholar who established the center of his sect in Ardabil and had a significant audience members. After his death, the tomb and khanegah of the Sheikh Safi al-Din has led to the emergence of the most magnificent works in Safavid architecture and art. In this context, the Safaviyyah sect is not only a mystical movement and a religious system of thought, but rather an important core of cultural formation. The administration of this sect was carried out in partnership with the sheikhs and the shah, which has developed and changed throughout the history of the Safavids, was made visible in the ceremonial and architectural arrangements of the Sheikh Safi al-Din Khaneghah. The subject of this research is Sheikh Safi al-Din Khanegah and Shrine which emerged and developed in the context of the relationship between mysticism and art. This complex has been examined from a religious, social and political point of view so far, and the reflections of this journal to the art environment of the period and the aftermath have not been sufficiently evaluated. However, the reflections of this khanegah on the art scene of the period and after periods were not evaluated sufficiently. The main aim of this article is to evaluate Sheikh Safi al-Din's Khanegah and Shrine protection and architectural structures during the Safavid history. Also, in the article, it is another goal to reveal how Safavid transfers his belief codes through artistic origin within the scope of Sheikh Safi al-Din Lodge.
\end{abstract}

Keywords: History of Islamic Arts, Sheikh Safi al-Din, Sheikh Safi al-Din Khanegah and Shrine, Ardabil, Chini Khaneh, Art Patronage

Res. Asst. Dr., Çukurova University, Faculty of Divinity, Department of History of Turkish Islamic Arts, ayseersay@hotmail.com, ORCID: 0000-0002-0314-6182 


\section{Giriş}

Asıl adı Şeyh Ebü'l-Feth Safiyyüddîn İshâk olan Safiyyüddîn Erdebîlî (d. 1252/3-ö. 1334) Safevîyye tarikatının kurucusudur. Bu tarikat Safevîler'in kurucusu Şah İsmail'in de mensup olduğu tarikat olması dolayısıyla Safevî Hanedanlığı'nı kuran asıl maya olarak telakki edilir. Safiyyüddîn Erdebîlî M.1334 yılında vefat ettiğinde, Erdebil'in surlarının dışında hankahının ${ }^{1}$ hemen yanında kule şeklinde bir anıt mezara defnedilmiştir. İşte Safevî Dergâhının özü olan bu türbe daha sonraki dönemlerde Safevî hanedanlığının ve tarikat önde gelenlerinin buraya gömülmesinin ardından tarikat mensuplarının ziyaretlerinin odağı haline gelmiştir. ${ }^{2}$

Erdebil'deki bu dergâhın tamamen Şiî düşüncenin yönetim yeri olması nedeniyle zaman içinde tasavvufi duruşunun önüne geçen siyasal duruşu bu merkezin temel yönlerinin göz ardı edilerek değerlendirilmesine sebep olmuştur. Özellikle de bu siyasi bakış açısı dergâhın tarihsel ve sanatsal birikimini bağımsız ve hakkını vererek görebilmenin zaman zaman önüne geçmiştir. Tarihi olaylar bu yapılar topluluğunu salt Safevîler ve Şiîlerle bağlantılı olarak yorumlamaya neden olmuştur. Oysa bu külliye Safevî ve Şiî çevrelerin merkezi olmasından ziyade kendi sosyolojik gerçekliğinde ortaya çıkmış kültürel ve sanatsal mirasının nicel ve nitel aktarıcısıdır. Buna göre yeni bir yaklaşım çerçevesinde Şeyh Safiyyüddîn türbe ve yapılarını sanat tarihi açısından değerlendirilerek buradaki yapısal bütünlüğü ve kurguyu merkeze alarak yeni baştan çözümlemeye dikkat çekilmelidir. Özellikle tarikatın geleneğindeki sanatseverliğin Safevî tarihi boyunca devam etmesi kayda değer bir durumdur.

Hankah: İslam dünyasında tarikat yapılarına verilen adlardan biri olan hankah, bölge ve zaman faktörlerine bağlı olarak farklı nitelikte tesisleri tanımlamaktadır. Tasavvuf tarihinde zühd hayatının tasavvufa dönüştügü, fakat henüz tarikat şeklinde teşkilatlanmamış bulunduğu VIII. yüzyılın ikinci yarısında, İslam mimarisi tarihinde ilk tarikat yapılarının öncüleri olan tesisler arasında hankah adıyla anılanlara rastlanır. $\mathrm{Bu}$ devirde özellikle İran- Türk kültür mirasının hâkim olduğu Batı Türkistan ve Horasan yörelerinde, hayatlarının önemli kısmı yolculuklarda geçen ilk sûfîlerin konaklaması için kurulmuş bazı hankahların varlığı tespit edilmektedir. Baha Tanman, "Hankah", Türkiye Diyanet Vakfi İslam Ansiklopedisi, (İstanbul: TDV Yay., 1997), 16: 43.

2 Bu dergâh bilhassa İran başta olmak üzere Müslüman coğrafyada halen yaygın etkisini sürdürmekte olup Unesco tarafindan Dünya Kültür Mirası yapılarından biri olarak belirlenmiştir. Bkz. Ece Kumkale Açıkgöz ve Yousef Daneshvar Rouyandozagh, "Selective Re-Creation Of Remembrances: The Case Of Sheikh Safi Al-Din Khānegāh And Shrine Ensemble İn Ardabil, Iran”. İdealkent 7, (2016): 402-426. 
Şeyh Safiyyüddîn Dergâhı bütünsel olarak değerlendirildiğinde, yap1 ve teşkilatın kurgusunda sahip olunan birikim ve öncelik unsurları dikkate alındığında bu külliyenin gündelik hayatın sanat başta olmak üzere neredeyse tüm alanlarını kapsadığı görülebilir. $\mathrm{Bu}$ yapılar bütününü sadece dini ya da siyasi bir merkez olarak görmek onu ortaya çıaran felsefi yaklaşım kadar pratik olarak sahip olduğu organizasyon şemasını da gösteremeyeceği ve anlamlandıramayacağı için kişiyi eksik bir yargıya götürecektir. Çünkü Şeyh Safiyyüddîn Dergâhı sadece inançsal olarak kendine bağlanan müritler için önemli bir merkez değildir. Dönemin sosyokültürel ve entelektüel ortamına 1şık tutan bir yapılar bütünüdür. Bugüne ulaşan bu yapılar topluluğunu işlevlerine göre okumak o dönemde tasavvuf ve toplum ilişkilerine derin bir okuma yapmayı zorunlu kılacaktır. Ayrıca Şeyh Safiyyüddîn Erdebilî, Türk-İslam kültür tarihinde Ahmed Yesevî, Hacı Bektâş̧-1 Velî, Mevlânâ Celâlüddîn-i Rûmî gibi fikir önderleriyle ve toplumu yönlendiren önemli isimlerle kıyaslayabileceğimiz bir şahsiyettir. ${ }^{3}$

Genellikle Erdebil halıları ve Şeyh Safiyyüddîn Dergâh'ında yer alan Çinihâne dışında pek çalışma yapılmamış, ${ }^{4}$ derinlemesine araştırmalar son yarım yüzyılda artmıştır.

Erdebil'deki Şeyh Safiyyüddîn Türbe ve Dergâhı hem dünya kültürü hem de İslam medeniyeti için sanatsal ve mimari bir şaheser olarak evrensel

Namiq Musalı, "Şeyh Safi Velâyetnâmesi: Tahkiki ve Transkripsiyonu", Türk Kültürü ve Hacı Bektaşı Veli Araştırmaları Dergisi 84, (Kış, 2017): 185.

4 Bu konuda en eski ve önemli kaynak farklı nüshaları olan Sarîhu'l-mülk adlı el yazması eser olup, Safevi tarihinde (17 ve 18. yüzyılın başları için) en temel kaynaktır. Altı kilo ağırlı̆̆ında, 363 varak büyük ebatlı bir el yazması olan bu tarihi kaynak 898/1493 yılında tamamlanmıştır. Bunlar İran Bastan Müzesi ve Tahran Milli Kütüphanesi’nde mevcuttur. Bkz. Leyla Yıldız, Kızlarım İçin Bir Vakıf Hatun Can Begüm ve Tebriz'de Gök Mescid'in Karakoyunlu Vakıfları, Marmara Türkiyat Araştırmaları Dergisi 2, no. 2 (Sonbahar 2015): 251-266.

Arthur Upham Pope, Chinese Porcelains from the Ardebil Shrine, (New York, 1956), Sheila Blair, "Texts, Inscriptions and the Ardabil Carpets," Iran and Iranian Studies: Essays in honor of Iraj Afshar, ed. Kambiz Eslami (Princeton: Zagros Press, 1998): 137-47, Lisa Golombek and Donald Wilber, The Timurid Architecture of Iran and Turan, (Princeton, 1988), Robert Hillenbrand, Safavid Art and Architecture, (London: 1998, by Jonhn Spencenr Trimingham), Lisa Golombek, "The Cult of Saints and Shrine Architecture in the Fourteenth Century" Near Eastern Numismatic, Iconography, Epigraphy and History, ed. D. K. Kouymjian, (Beirut, 1974), :419- 430, Monika Gronke, Derwische im Vorhof der Macht: Sozial-und Wirtschafttsgeschichte Nordwestirans im 13. und 14. Jahrhundert, (Stuttgart: Franz Steiner, 1993), Fariba Zarinebaf-Shahr, "Economic Activities of Safavid Women in the Shrine-City of Ardabil," Iranian Studies 31, no.2, (1998) :247-261. 
değere sahip yapılar topluluğudur. Bu külliye ayrıca belli bir tasavvufî geleneğin temel ilkelerinin temsilini aktarmasıyla dikkat çeker. Bu ilkelerin başında gelen zikir, inziva, ilim gibi Safevî tarîkini yani inanç yolunu ve derslerini sembolik olarak tanımlayan ögeler, mimarinin mekânsal organizasyonunda yer alır. Ayrıca tasavvufi ilkeler kitabeler başta olmak üzere süsleme programında ifade edilir. Bu durum dergâhın tüm dekoratif unsurları, yazıtlar ve diğer süslemeleri de dahil olmak üzere adeta Safeviyye tarikatının mistik kavramlarına ve felsefesine hizmet etmek için oluşturulduğunu gösterir. Buna ek olarak dergâh hem İslam kültüründe, mimaride ortaya çıkan ideolojik ve entelektüel değerler açısından hem de mimari teknikler ve yöntemler ile ortaya koyduğu yenilikler ve bütünlükler yönünden özgündür.

Türbenin ve dergâhın mimari gelişim ve teknolojisine bakıldığında, İran'ın kendine özgü İslam mimarisi ve komşu ülkelerin sanat ve mimari geleneklerinden alıntılar dikkat çeker. Şeyh Safiyyüddîn Dergâhı yapılarının sanatsal ve mimari tasarımı, İlhanlı ve Timurlu mimarisi gibi eski ve çağdaş kaynaklardan gelen etkilere ve bunları tasavvuf felsefesiyle bütünleştiren yeni uygulamalara dayanıyordu.

Tarikatın kuruluşundan itibaren tek merkezinin Şeyh Safiyyüddîn Dergâhı olduğu kabul edilen Safevî tarikatı, aynı zamanda İslam tasavvufundaki eski inanç ve değerlerin varisidir. Erdebil şehrinin manevi hayatında önemli bir yeri olan dergâhın faaliyetleri İlhanlı hükümdarı Gazan Han ile veziri tarafından desteklenmekteydi. Faaliyetlerini Deştikıpçak ve Kırım gibi bölgelerde de sürdüren Şeyh Safiyyüddîn karizması ile Safevîyye tarikatı çok geniş bir çevreye yayılmış, Azerbaycan başta olmak üzere Gilan, Taberistan (Mazenderan), Horasan, Buhara, Türkmenistan, Türkistan, Karahıtay, Çin Türkistanı, Hindistan, Serendib (Seylan), İran, Irak, Suriye, Lübnan, Hicaz, Anadolu ve Rumeli bölgelerinde binlerce müride sahip olmuş, bütün bu coğrafyada Erdebil'deki merkeze bağl1 tekkeler kurulmuştur ${ }^{5}$ (Resim 1).

Şeyh Safiyyüddîn Dergâhı hem İran coğrafyasında hem de İslam dünyasında diğer tasavvufi külliyelerin yapılarından çeşitli örnekleri bünyesinde toplamıştı. Şeyh Safiyyüddîn Dergâhına örneklik teşkil etmiş olabilecek

Reşad Öngören, "Safevîyye”, Türkiye Diyanet Vakfi İslam Ansiklopedisi, (İstanbul: TDV Yay., 2008), 35: 460. 
İran'daki yapılar arasında Sultaniye Bâyezîd-i Bistâmî Hankah ve Türbesi Kompleksi, Sultaniye Çelebioğlu Hankah ve Türbesi, Şeyh Ahmed Cem Hankah ve Türbesi, Şeyh Nimetullah Veli Hankah ve Türbesi kompleksi, Natanz Şeyh Abdussamed Hankah ve Türbesi, Şeyh Şehâbeddin Mahmud Ahari Hankah ve Türbesi gösterilebilir. ${ }^{6} \mathrm{Bu}$ merkezler de tıpkı Şeyh Safiyyüddîn örneğinde olduğu gibi türbe olarak ortaya çıkmış ve yavaş yavaş gelişerek kutsal ve sosyo-kültürel merkezlere dönüşmüştür.

\section{Safevîlerde Tarikat-Devlet İlişkisi}

Safevî şahlarının, otoritelerini sergilemek maksadıyla, başkenti ve sarayı korudukları gibi gücün temsili için Şeyh Safiyyüddîn Türbe ve Dergâhını himaye ettikleri görülür. Şeyh Safiyyüddîn'nin türbesi Safevîhanedanlığının erken dönemlerinden itibaren hanedan halkı ile ilişkilendirilmişti ve onun mimarisi, şahın hem dini hem de dünyevi otoritesini kapsayacak şekilde gelişmekteydi. Sarayın ve dergâhın işlevi ve anlamında derin farklılıklar vard1, ancak araştırmalar genel olarak Safevî döneminde bu iki kurumun birçok özelliği paylaştığını ortaya koyar. Örneğin Şeyh Safiyyüddîn külliyesinin şaha ait iki sembolik yapı olan Çinihâne ve nakkarhaneye sahiplik etmesi buna örnekti. Benzer şekilde, Şah I. Abbas'ın İsfahan'daki sarayında, kurbanların hazırlanması için kullanılan şerbethanelerin yanı sıra, sûfîlerinin zikredecekleri bir tevhidhane vardı. Yönetimdeki şeyh ve şahın ikiliği böylece Safevîlerin erken dönemindeki mimari projelerinde de görüldü. ${ }^{7}$

İmami Şiîliğini benimsemiş ve zamanın önde gelen sûfî tarikatlarından birinden neşet etmiş olmaları, Safevî devlet politikaları ve ideolojisinin temeli niteliğindeydi ve onları, sadece çağdaşları olan Osmanlı ve Bâbür devletlerinden değil, aynı zamanda kendilerinden önce İran topraklarında kurulan İslam devletlerinden de ayıran özellikler arasındaydı. ${ }^{8}$

ICHHTO, Sheikh Safi Al-Din Khanegah And Shrine Ensemble In Ardabil Nomination Report. UNESCO World Heritage Convention Nomination of Properties for Inclusion on the World Heritage List, Tehran, 2009,342.

7 Rizvi Kishwar, "Transformations in Early Safavid Architecture: The Shrine of Shaykh Safi al-din Ishaq Ardabili in Iran (1501-1629)", (PhD diss., University of Harvard, 2000), 245.

8 A. Damla Anar Gürkan, "Safevî Şahlarının Baniliği Üzerine Bir Değerlendirme”, İran Çalışmaları Dergisi 1, no. 1, (Bahar 2017): 120. 
İslam coğrafyasında tarikat-devlet kurumları tarih boyunca daima yakından birbirini izleyen bir görünümde olmuştur. Hemen her tarikata ait birçok tekkenin faaliyet gösterdiği Osmanlı topraklarında devlet yöneticileriyle tekke mensupları arasındaki münasebetler de dikkat çekicidir. Osmanlı'nın kurucusu Osman Gazi'nin bir tekke şeyhi olan Edebâli ile ilgisi, Orhan Gazi tarafından 1331'de İznik'te açılan ilk medresenin başına Dâvûd-i Kayserî'nin getirilmesi, Yıldırım Bayezid'in Emîr Sultan, Fâtih Sultan Mehmed'in Akşemseddin'le ilişkileri, kuruluş safhasında olan devletle tekke mensupları arasındaki yakın temasların örnekleridir. Bununla birlikte Osmanlı devleti daima tarikatlara mesafe konusunda titiz davranarak, onların suiistimallere karşı kontrol altında tutulmasını gerekli görmüştür. Zaman zaman devletin idarecilerine karşı çıkan sûfîler görülmüştür. Bu durumda Osmanlı devletin bekâsı için oyunu tarikatlar aleyhine kullanmıştır. Bunun Osmanlılar'da en meşhur örneği Kadızâdeliler-Sivâsîler tartışmasıdır. Ki bu sorunlar sonucunda XVII. yüzyılda İstanbul'da tarikat ritüelleri ile ilgili önemli yasaklar gelmiştir. ${ }^{9} \mathrm{Bu}$ nedenle Osmanlı Devleti'nde tarikatlarla ilişkiler daima mevcut olmakla birlikte bu yakınlığın dereceleri devre göre değişkenlik göstermiş ve hiçbir zaman bir tarikatın merkezliğinde siyaset belirlenmemiştir. Safevî Devleti ise bu bağlamda diğer Müslüman çağdaş devletlerden ayrılmaktadır. Zira Safevî Devleti'nin yaklaşık iki yüzyıllık ömrü boyunca Erdebil'deki dergâhın merkezi yönetimdeki ağırlığı neredeyse hiç değişmemiştir.

Safevî Devleti'nin adı bile, Şah İsmail'in soyunun dayandığı Safiyyüddîn-i Erdebîlî'den gelmektedir. Öyle ki Safevî tarikatının Safevî Devleti'ne uzanan tarihini bazı araştırmacılar 1301- 1447 yılları arası Safevî tarikatı dönemi, 1447-1494 yılları arası Erdebil' de dini devlet dönemi ve 1501-1722 arası Safevî milli devlet dönemi olarak bölümler. ${ }^{10}$ Tarihsel süreç zaman içinde büyüyen, genişleyen ve ihtiyaçları çoğalan tarikatın gelişimine dair veriler dergâhın da yapılaşmasını derinden etkilemiştir. Sünni ve orta yollu bir tarikatın zaman içinde Şiî merkezli, katı ve aşırı bir cereyana dönüşmesi dini düşünce dönüşümünden ziyade devrin siyasi yapısıyla ilgilidir.

Mustafa Kara, "Tekke", Türkiye Diyanet Vakfi İslam Ansiklopedisi, (İstanbul:TDV Yay., 2011), 40: 369.

10 Hinz Walther, Uzun Hasan ve Şeyh Cüneyd, çev. Tevfik Bıyıkoğlu, (Ankara: Türk Tarih Kurumu Bas., 1992), 2. 
Safiyyüddin-i Erdebîli döneminde İlhanlı hükümdarı Gazan Han'ın desteğini gören tarikat, ondan sonra şeyhin yerine geçen oğlu Sadreddin-i Erdebilî (ö. 794/1392) zamanında ise Altın Orda Hanı Canbeg ve devrin valisi tarafindan himaye edildi. Kaynaklara göre Timur da Sadreddin-i Erdebilî’ye güven ve saygı duymuştur. Sadreddin-i Erdebilî yerini Hace Ali (ö. 832/ 1429) sanıyla bilinen oğlu Alaeddin-i Erdebilı̂’ye bıraktı. Timur'un Ankara Savaşı'ndan dönüşünde (1402) Hace Ali'yi ziyaret ederek etkisi altında kaldığı ve Erdebil'i köyleri dahil olmak üzere bu tarikata bağışladığı kaynaklarda belirtilir. Timur'un veliahtı olan Şahruh Mirza, 823 (1420) tıpkı babası gibi bu tarikata olan bağlılığını Karakoyunlular'la savaşa gideceği zaman Şeyh Safiyyüddin'in türbesini ziyaret ederek ve posta oturan Hace Ali ile görüşüp ondan dua isteyerek göstermiştir. Hace Ali'den sonra Erdebil'deki tekkede onun oğlu İbrahim (Şeyh Şah) (ö. 851 /1447) şeyh oldu. Ondan sonra ise tarikatın başına geçen oğlu Şeyh Cüneyd ile Safeviyye siyasi kimlik ile anılan bir karakter kazand1. İlk kez tarikatta iki farklı şeyh tartışması baş gösterdi. Şeyh Cüneyd'in amcası Şeyh Cafer ile farklı iki grup ortaya çıktı. Cüneyd'in Şirvanşah Sultan Halil ile bir savaşta hayatını kaybetmesinin ardından (ö. 864/ 1460) kalan müritleri oğlu Haydar'ın etrafinda birleşti. ${ }^{11}$

Şeyh Haydar devrinde Erdebil tam bir askeri ordugâh halini aldı. Haydar babasının yarım bıraktığı saltanat davasını tamamlamak için tekkesini ve odalarını silah deposu haline getirdi. Bir İran tarihçisi ilk kez burada "kalem yerine kılıçlar gördüğünü" yazar. Kendisi de silah ustası olan şeyh burada silah imal edip, ordu için asker yetiştiriyordu ${ }^{12}$. Dedesi Şeyh Cüneyd (ö. 864/1460) ve babası Şeyh Haydar'ın (ö.893/1498) çabalarıyla gelişen Kızılbaşlık ideolojisi Şah İsmail (s.1501-1524) tarafindan en olgun noktasına eriştirilmiştir. O, Hatai mahlası ile yazdığı şiirlerle kızılbaşlık öğretisinin en temel kaynaklarını oluşturmuştur. ${ }^{13}$

Safevîyye Tarikatı'nın yönünü değiştiren ikitemel değişim olan siyasallaşma ve Şî̂leşmenin birtakım nedenleri vardır. Bunlar tarikatın kurucusu Şeyh Safiyyüddîn Erdebilî'nin ölümünden sonra İlhanlı Devleti'nin çöküşü ile bölgede üstün gücün olmaması, Timur'un Ankara Savaşı sonrasında

\footnotetext{
11 Öngören, "Safeviyye", 460-461.

12 Mehmet Çelenk, "16 ve 17. Yüzyıllarda Safevî Şiîliğì", (Doktora Tezi, Uludağ Üniversitesi, 2005), 45.

13 Mehmet Çelenk, "16 ve 17. Yüzyıllarda Safevî Şî̂liğì”, 54.
} 
Hoca Ali'nin etkisiyle Türkmen esirleri serbest birakması ve Erdebil ve civarındaki toprakları gelirleriyle birlikte tarikata bağışlaması, konar göçer Türkmenlerin Sünnî Osmanlı'nın hakimiyetinden rahatsızlık duyarak Erdebil'i sığınak olarak görmeye başlamasıdır. Tarikatın, varlı̆̆ını ispatlamak için bir siyasi güç olarak ortaya çıkması, bölgede bulunan devletler ile temas kurmasını kaçınılmaz kılmıştır. ${ }^{14}$

\section{3. Şeyh Safiyyüddîn Türbesi ve Dergâhı}

Bir tarikatın veya tarikat kolunun merkezi olan tam teşekküllü tekkeler için kullanılan âsitâne ve dergâh ${ }^{15}$ kavramının tanımına uyan bu merkez belli başlı bölümleri içermekteydi. Sıradan her dergâhta bulunan şeyhin veya haleflerinin gömüldüğü türbe, mescit, Kur'an ilimlerinin verildiği dârülkurrâ ya da dârülhuffâz gibi mekanlar, tasavvufi ritüellerin yapıldığ odalar, şeyhin ailesinin ve yakınlarının ikamet ettiği evler, bahçe ve hazire gibi birimlere zaman içinde kültürden kültüre göre değişen ek yapılar ilave edilmiştir.

Şeyh Safiyyüddîn' in türbesinde, şahlık döneminin başından itibaren en çok tartış1lan konu yönetimi meselesiydi. Türbenin gözeteni olan mütevelli, manevi ve idari otorite postunu miras alan şeyhin yardımcısı olacaktır. Kaynaklar bu konuda 16. yüzyıldan itibaren, Şeyh Safiyyüddîn'in soyunun ya da kayınpederi Şeyh Zâhid Gîlânî'nin soyundan olan Safevî ailesinin farklı aileleri arasında bir çatışma yaşandığını gösteriyor. Zahidi ve Safevî ailelerinin mensupları türbenin haklı velileri olduğunu iddia etmiştir. Bununla birlikte, mütevelliyi tayin etmek, tarikatın başlı başına kendisi olan Şah'ın ayrıcalığıydı. Böylece seçilen kişi şahı ve dolayısıyla siyasi temayülünü temsil etti; bazen bu bir Kızılbaş iken daha sonra hanedanlıkta önemli kişilerden biri idi. ${ }^{16}$ Mütevelli, türbenin manevi hâmisi olduğu kadar fiziksel bakımından sorumluydu.

Dergâhın canlılığı, Erdebil şehrinin kentsel gelişimi üzerinde etki göstermiştir. Şehrin ana merkezi olan çarşıdaki dergâh birçok mülke

14 Hatice Aksoy, "Safevîyye Tarikatının Şî̀leşme ve Siyasallaşma Süreci”, (Yüksek Lisans Tezi, Selçuk Üniversitesi, 2016), 6.

15 Baha Tanman, "Âsitâne", Türkiye Diyanet Vakfi İslam Ansiklopedisi, (İstanbul:TDV Yay., 1991), 3: 486.

16 Rizvi Kishwar, “Transformations in Early Safavid Architecture:...”, 240. 
sahip olduğu için ticaretin kalbinde önemli bir finansal etkiye sahipti. Türbenin yöneticileri ayrıca, birçok mağazanın kısmî mülkiyetine sahip olduklarından, pazardaki birçok tüccarın iş ortaklarıydı. Ayrıca kaynaklar Safevîyye tarikatının ilk destekçilerinin Erdebilliler olduğunu belirtir. Şah İsmail'in saltanatına kadar dergâh sayesinde Erdebil'de ciddi bir demografik değişime şahit olunmadı. O zamana kadar, türbe mensuplarının ve ziyaretçilerin çoğunluğu kentin sakinleriydi. ${ }^{17}$

Netice olarak bu yapılar topluluğunun bugüne ulaşan mimari unsurları şu şekildedir: Haramhane (1324), Şeyh Safiyyüddîn Türbesi (1345), Dârülhuffâz (ilk inşa 14. yy., yeniden inşa 16. yy.), Şahnişin hücresi (ilk inşa 14. yy., yeniden inşa 1612), eski inzivahane (Çilehane) (14. yy.), yeni inzivahane (ilk 14. yy., yeniden inşa 1570), Çinihâne (ilk yapım tarihi bilinmiyor, yeniden inşa 1612) Dârülhadis, Şah İsmail Türbesi (152429), Şah Tahmasp avlusu (1570'den önce), Cennetsaray (1537) olarak siralanabilir.

Bununla birlikte dergâhta kuruluşundan itibaren mevcut ola pek çok bina günümüze ulaşamamıştır. Son yapılan kazılardan neticesinde külliyenin şunlardan oluştuğunu söyleyebiliriz: Haramhane, Çilehane, Künbedhane, Şah İsmail Türbesi, Dârülhuffâz, Şah Nişin, Cennetsaray (sema ve ayin yeri), Dârülhadis (Dâru's-Selâm ya da misafirhane), Şah Abbas cephesi (Molla girişi), Şehidgâh mezarlığ1, orta avlu (giriş revakı), bahçe avlusu (büyük avlu), Şeyh hamamı, Mabed kapısı, Âli Kapu ön cephesi, eski çilehane, aşhane, hamam ve mutfak, firın, şerbethane, okul ve duvarı, sakahane, nakkarhane, defterhane, su değirmeni ve ambar (Resim 2, 3).

\section{Dergâh Yapıları}

\section{1. Şeyh Safiyyüddîn'in Türbesi- Allah Allah Kubbesi}

Dergâhın çekirdeğini oluşturan yapı kuşkusuz Şeyh Safiyyüddîn'in Allah Allah kubbesi olarak da anılan türbesidir. Kaynaklara göre, Şeyh Safiyyüddîn'in evi ve dergâhı aynı yerdeydi ve o da vefat edince (ö. 735/1334) evi ve bahçesinin yanındaki bir odada, mezarının inşa edildiği binada defnedildi. Burası, bahçedeki havuzhânenin ve müritlerin

17 Rizvi Kishwar, “Transformations in Early Safavid Architecture:...”, 238-239. 
mezarının bulunduğu halvetsarâyın olduğu yerdir (Resim 4, 5, 6, 7, 8). Sonraki dönemlerde burası dinî ve mezhebi açıdan büyük bir önem kazanmıştır ve Şâh İsmail'in yanı sıra bazı Safevî hükümdarları da buraya defnedilmiştir. Büyük vakıflarla beslenen bu külliye Şâh I. Abbâs (s.15871629) zamanında yeniden imar edildi. Abbâs ayrıca Şeyh Safiyyüddîn'in türbesini altın kaplamalarla süsletti ve pek çok kitabı da buraya vakfetti ${ }^{18}$.

Şeyh Sadreddin'in (Şeyh Safiyyüddîn'in ikinci oğlu) yaptırdığı Şeyh Safiyyüddîn'in türbesi içten sekizgen, dış kısmı da yuvarlak bir kuledir. Türbenin şekli silindir bir kule biçiminde olup küre şeklinde bir kubbe ile örtülmüştür. Üstünde Allah Allah yazan kubbenin oturduğu bu kulenin çevresi 22 metredir. 1.5 metre yüksekliğe kadar bir duvarın sekizgen kaidesi, tabanı üzerine yerleştirilmiştir ${ }^{19}$. Toplam yükseklikleri (duvar, kule ve kubbe kaidesi) yaklaşık 17,5 metredir. Bu silindir biçimindeki kısmın gövdesi turkuaz-gri renkteki sırlı tuğlalarla Allah yazısını oluşturacak şekilde dizilmiş ve köşelerinde mavi-beyaz renkle, Kur'ân ayetleriyle süslenmiştir.

\section{2. Şah İsmail Türbesi}

Şeyh Safiyyüddîn'in mezar kulesi ve haremhane arasında küçük bir kubbeli yapı öne çıkar. Türbe avlusu ve mezarlıktan görülebilen kubbe Şah İsmail'in (d. 1487-ö. 1524) türbesine aittir (Resim 9 a, b). Türbe Şah'1n ölümünden sonra eşi Taçlu Hanım tarafindan yaptırılmıştır. Dışı sekizgen bir kaidenin üzerinde durur. 2/42 × 2/65 m ölçülerindeki bu bina, Safevî hanedanının kurucusu olan ve bir asırdan beri İran'ın Şahı olarak hüküm süren biri için çok mütevazıdır. Bu türbenin kapladığı alan, İran'daki siyasi öneme sahip diğer benzer örneklere göre oldukça küçüktür. Tabi ki, bu noktay1, bu bölümün bir hanedanlığının mezarlığı olmasıyla açıklayabiliriz. Çünkü Şah İsmail, Şeyh Safiyyüddîn'in dört yardımcısı yanına gömüldü. Onlar için de bazı türbeler düzenlenmiş olabilir, ancak daha sonra mezarlar bu

18 Serap Şah, “Safvetü’s-Safầ'da Safiyyüddîn-i Erdebîlînnin Hayatı, Tasavvufî Görüşleri ve Menkıbeleri”, (Doktora Tezi, Marmara Üniversitesi, 2007), 63.

19 Habib Shahbazi Shiran, "Archeology and Architectural Aesthetics of Jannat-sara Mosque and Haramkhana, Two Buildings Located Within the Monument Sheikh Safi Al-Din Ardabili, Ardabil World Heritage, in Iran", Research Journal of Recent Sciences 4, no.9, (September 2015): 98. 
külliyenin yüzyıllar boyunca tecrübe ettiği inşaat, yenileme ve yıkım gibi olaylar nedeniyle günümüze gelememiştir. ${ }^{20}$

Türbenin silindirik kasnağında, çoğu tahrip olmuş geniş bir yazı kuşağı vardır. Burada beyaz zemin üzerine mavi celi sülüs yazı ile kasnağın içinde turkuaz mavisi kûfî tarzda "Ali” yazan koyu mavi laciverdî elmas desenleri vardır. Şah II. Abbas (s.1642-1666) Şah İsmail'in türbesinin çatısını tamir ettirmiştir.

\subsection{Haremhane (Muhyiddin Muhammed Türbesi)}

Muhyidddin Muhammed türbesi, muhtemelen en büyük oğlunun ölümünü anmak için Şeyh Safiyyüddîn'in kendisi tarafından yaptırdığı külliyedeki en eski yapıdır. Bina plan olarak 5 metrekare ve kubbelidir, şu anda iki alan üzerinden Dârülhuffâz'a bağlanmıştır. Yapı malzemesi tuğladır. Kasnak kaidesinin ve kubbenin onarıldığı ve eskiden güney köşesine tutturulmuş bir sütunun kaldığı anlaşılmaktadır.

Kubbe kasnağını çevreleyen kısım çok renkli sırlı çini mozaiklerle süslenmiştir. Bunlar, mezar kulesi ve haremhane kubbelerinde sırlı tuğla ve çinilerde aynı elmas şeklindeki deseni göstermektedir. Haremhane, Şeyh Safiyyüddîn'in hayattayken inşa edilmiş bir mezarlık alanıydı. Ancak, Şeyhin neden oğlunu, zaviyesinin yakınındaki mezarlıktan ziyade evine gömmeyi seçtiği sorusunun yanıtı net değildir. Sonraki yıllarda, bu oda hanedanın dergâhtaki dinlenme yeri oldu. Şeyh Safiyyüddîn'in şeyhi Zâhid Gîlânî’nin kızı olan karısı Bibi Fatıma H. 724 (M. 1324) tarihinde Erdebil'de vefat etti. Şeyh Safiyyüddîn'in emri üzerine o buraya defnedildi ${ }^{21}$. Buradaki diğer mezarlar, Şeyh Safiyyüddîn'in (karısı, kızı ve oğlu) yakın ailesi ile, Şah İsmail'in devrinde görev yapan akraba ve görevlilerden oluşuyor (Resim 10).

Yapının şu anki adı orijinal değildir ve burası aslında Safevî döneminde kullanılmıyordu. O döneme ait kapsamlı ve önemli bir el yazması kaynak olan Sarîh 'ül-mülk'te de buradan söz edilmez. Yapıya bu adın verilmesinin sebeplerden biri, bu odanın Şeyh Safiyyüddîn'in mezar kulesini ve Şah İsmail'in mezarını içeren kutsal bölgelerin 'harem'in bir parçası olarak

\footnotetext{
20 Habib Shahbazi Shiran, "Archeology and Architectural Aesthetics...”, 98.

21 Habib Shahbazi Shiran, “Archeology and Architectural Aesthetics...”, 98.
} 
görülmesi olabilir. Kubbenin çevresine yayılan ve kemerlerin altındaki bu alanda gömülen kişiyi, Muhyiddin Şeyh Safiyyüddîn'nin oğlu olarak adlandıran bir yazı kuşağı vardır. ${ }^{22}$

Tasarımı Şeyh Safiyyüddîn'in türbe kubbesine benzeyen, rengârenk ve süslemesiz tuğla örgüsünü çevreleyen kubbe yuvarlaktır. Türbenin içinde duvarların neredeyse kare şeklinde olduğu bir koridor, sundurma veya oda barındırmaktadır. Ana giriş, doğu duvarının kuzey ucunda, gümüş plakalı bir çift ahşap kapıdan oluşur. Türbenin içine mavi metin üzerinde beyaz harflerle yazılmış bir kitabe kubbe kasnağını çevrelemektedir ve dördü periyodik olarak yerleştirilmiştir. Burada Rahman Suresi'nin 26 ve 27. ayetleri celî sülüs hatla yazılmıştır (Resim 11).

\section{4. Şahnişin}

Şahnişin ${ }^{23}$, türbenin, güneybatı (kıble) tarafında Dârülhuffâz'ın iç kısımdaki eklenmiş bölümdür. Şeyh Safiyyüddîn Türbesi'ne ve Dârülhuffâz'a bitişik olarak yaptırılan yarı sekizgen bir odadır. Şah I. Abbas zamanında (15871629) 1611'de yaptırılan ve teşrifat için kullanılan, "Şahnişin" Dârülhuffâz'a benzer bir taş kaide üzerinde yükseltilmiş, her iki tarafinda iki pencere açıklığı bulunan açılı bir niştir ${ }^{24}$. Avluya bakan taraf tuğlada örülmüştür. Dârülhuffâz'in aksine pencereler mozaik karolarla çerçevelenmiştir. Türbenin şahnişine bağlı olduğu kuzeybatı kesiminde mavi tuğla yoktur, bunun orijinal olarak başka bir yapı tarafından örtülmüş veya maskelenmiş olduğunu düşündürmektedir ${ }^{25}(\operatorname{Resim} 12 \mathrm{a}, \mathrm{b}, 13)$. Şahnişin temelde iki basamaklı merdivenle yükseltilmiş ve bir kapısı olan uzun bir gümüş 1zgara ile çevrelenmiş mihraba benzer bir platformdan oluşur. Şah Abbas, harem ve Safevî mezarlarına erişimi kısıtlayan görkemli Şahnişin ve gümüş ızgarayı inşa ederek, Safevî hanedanlığının mirasçısı olarak onların gücüne vurgu yapmıştır. ${ }^{26}$

\footnotetext{
22 Rizvi Kishwar, "Transformations in Early Safavid Architecture:...", 69-71.

23 Şahnişin, eski Türk mimarisinde odanın karşı ön cephesinde yer alan üç yanı pencereli çıkma, anlamına gelir. Son erişim: 17 Nisan 2019, https://sozluk.gov.tr/?kelime $=\%$ C5 $\% 9 \mathrm{EAHN} \% \mathrm{C} 4 \% \mathrm{~B} 0 \% \mathrm{C} 5 \% 9 \mathrm{E} \% \mathrm{C} 4 \% \mathrm{~B} 0 \mathrm{~N}$

24 Rizvi Kishwar, "Transformations in Early Safavid Architecture:..., 187.

25 Rizvi Kishwar, “Transformations in Early Safavid Architecture:...”, 72.

26 Rizvi Kishwar, “Transformations in Early Safavid Architecture:...”, 193.
} 


\subsection{Dârülhuffâz (Kandilhane)}

Dârülhuffâz, ${ }^{27}$ M. 14. yüzyılın sonunda, oğlu veya torunu tarafından Şeyh Safiyyüddîn'in ölümünden sonra inşa edilmiştir. Dikdörtgen ibadethane $8.9 \mathrm{~m}$ x $5.8 \mathrm{~m}$ ebatındadır. Ancak uzun kenarların her birinde yaklaşık 3 metre derinliğindeki hücrelerle tüm yapının boyutları yaklaşık $11.5 \mathrm{~m}$ uzunluğunda ve $6 \mathrm{~m}$ genişliğindedir. ${ }^{28}$ Bu yapı Şeyh Safiyyüddîn Türbesi'ne geçişin yapıldığ 1 dikdörtgen mekandır (Resim 14, 15).

Dârülhuffâz'ın ön cephesi dergâhın avlusuna bakar. Binanın taş kaidesi yaklaşık bir metre yüksekliğinde, toplam yüksekliği ise yaklaşı 11 m'dir. Yapı pişmiş tuğla ve mozaik döşemeden inşa edilmiştir. Binanın yüksek kemerli eyvanı ve zirvesi tamamen turkuaz mavisi, lapis, beyaz ve kırmızı mozaiklerle dekore edilmiştir. Girişi sağlayan kemerli portal, her iki tarafa iki dar beyaz mermer sütunla çevrilidir. Yazı kuşakları portalin ve girişin çevresini kuşatır. Portalin yarım kubbe kemerindeki mukarnas-eyvanın daha küçük versiyonları, mum veya lamba koymak için yapılan niş taraflarında tekrarlanır. Yapının avluya bakan cephesinde her biri birbiri üstünde olmak üzere iki penceresi olan beş katlı demir zzgara penceresi vardır. Pencereler dikdörtgen formlu olup bu dikey bantlar turkuaz mavisi, lacivert, beyaz ve kırmızı çini mozaiklerle döşenmiştir. Alttaki pencere band1 temelin üstünden yükselir. Her birinde, 1zgara üstünde, mozaik kapl1, kemerli bir taş oyma; bunun üstünde de koyu mavi beyaz harflerle epigrafik bir panel vardır. Pencereler dar bir bitkisel mozaik çerçeve ile kuşatılmıştır. Her bir pencere topluluğu dekoratif açıdan özgün şekildedir.

Dârülhuffâz, şimdi Şahnişin adı verilen yarı sekizgen bir ek ile Şeyh Safiyyüddîn'in mezar kulesine bağlanmıştır. Burası, Dârülhuffâz'a benzer bir taş kaide üzerinde yükseltilmiş, her iki tarafinda iki pencere açılığ bulunan aç1lı bir niştir.

Avluya bakan taraf, tuğlalar, çini mozaiklerle çerçevelenmiş pencerelerle kaplanmıştır. Diğer taraf mezar kulesi ile Haremhane arasında sıkışmış ve bu yüzden süslenmemiştir. ${ }^{29}$

27 Asr-1 saâdet'te Mescid-i Nebevî'de başlayan ve daha sonra ashaptan bazılarının evleriyle ilk İslâm mabetlerinde devam eden kıraat ilmi eğitimi zaman içinde kurumlaşarak bu maksatla inşa edilen ve dârülkurrâ (dârülkur'ân, dârülhuffâz) adı verilen yapılarda sürdürülmüştür. Baha Tanman, "Darülkurra", Türkiye Diyanet Vakf Íslam Ansiklopedisi, (İstanbul:TDV Yay., 1993), 8: 545.

28 Habib Shahbazi Shiran, "Archeology and Architectural Aesthetics...”, 97.

29 Rizvi Kishwar, "Transformations in Early Safavid Architecture...”, 89. 


\subsection{Kümbet-i Şehzade /Çinihâne (Porselen evi)}

Külliyenin başlangıçta bağlantısız olan, ancak şimdi Dârülhuffâz'a bağlanan başka bir birimi de Çinihâne' dir. $^{30}$

Şeyh Safiyyüddîn Türbesi'ndeki en önemli ve kesin mimari dönüşüm, Şah I. Abbas tarafindan Çinihâne ve Dârülhuffâz'ın içini yenilediğinde gerçekleşti. Çinihâne içine gerçekten orijinal yapıyı kaplayan bir alçı kalıp, güzel bir şekilde oyulmuş ve ahşap bir kabuk yerleştirilmiştir. Burası bir dervişin ibadet mekânından daha çok bir saray için altınla kaplanmış ve süslenmiş bir bölümü andırır (Resim $16 \mathrm{a}, \mathrm{b}$ ). ${ }^{31}$ Şah Abbas'ın türbeye bağışlamış olduğu bu kıymetli çini eserler ve porselenler yoluyla, şimdiki Çinihâne olarak adlandırılan büyük ve gösterişli bölümü müze işlevi gören bir alana dönüştürdüğünü görüyoruz. Bina, Şah'ın kitap ve değerli eşyalarını topladığı için artık Safevîlerin özel koleksiyonunun korunduğu yere dönüştü. (Resim 17). Burası şu anda da türbe müzesi olarak işlev görüyor ve orijinal çini koleksiyonunun örneklerini içeriyor.

Şeyh Safiyyüddîn'in türbesinin yeri, 17. yüzyıl İran'ın sosyal ortamında hala önemliydi, ancak tek ayrıcalıklı türbe değildi. Safevîlerin dini otoritesi, Erdebil'deki atalardan kalma bu merkezden, Kum ve Meşhed'deki Şiî merkezlerine kaymıştı. Erdebil'deki tarikat mensuplarının siyasi alana katılımının en aza indirilmesiyle, İsfahan başta olmak üzere farklı şehirlerde ortaya çıkan üst sınıfın gücünün arttığı gözlemlenmiştir. Şeyh Safiyyüddîn Dergâhının Şah Abbas'ın mimari projelerinde somutlaştırılmış değişimi Safevînin sembolü olduğu yeni bir elit grubun doğmasına neden oldu. Dârülhuffâz ve Çinihâne iç mekanlarındaki ayrıntılı yenilemeleri, türbenin görkemini kalıcı hale getirdi. Bir anlamda türbenin kendisi de Çinihâne'de depolanan eserler gibi bir antika haline geldi ${ }^{32}$. Ayrıca Şah Abbas bu eser ve içindekilerle, sanat eserlerini toplayan ve sanat atölyelerinden destek veren şah cömertliğine vurgu yaptı.

Çinihâne tuğla ve harçtan yapılmış doğu-batı eksende uzanan büyük bir sekizgen yapıdır. Çapı yaklaşık $18 \mathrm{~m}$ ve alanı yaklaşık $9.7 \mathrm{~m}$ x 9.7 m.'dir. Şah I. Abbas zamanında, külliyesinin en eski yapılarından biri olan

\footnotetext{
30 Habib Shahbazi Shiran, "Archeology and Architectural Aesthetics...", 98.

31 Rizvi Kishwar, "Transformations in Early Safavid Architecture:...”, 241.

32 Rizvi Kishwar, "Transformations in Early Safavid Architecture:...”, 243.
} 
bu yapının içi tamamen yıkılmış ve binanın iç boyutlarını maskeleyen bir tahta kabuk yerleştirilmiştir. Binanın hem dış hem de iç kısımları, epigrafi eksiklikleri nedeniyle dikkat çekicidir. Belki de kubbe orijinalde süslenmiştir, ancak bu karo işlerinin hiçbiri günümüzde yoktur (Resim 18).

Mimari ve arkeolojik kanıtlar, asıl binanın ayakta durduğunu ve şu anda Dârülhuffâz'a bağlı bir ilk giriş eyvanı olduğunu göstermiştir. Sekizgen ilginç planlı yapı 16. yüzyıl tarihi kayıtlarına göre, kiremitli bir kubbe ile örtülüydü.

Alan, Dârülhuffâz'ın girişi olarak kullanılan dört ana girintiye ayrılmıştır. Her duvarın ortasında gömme dolaplı, beş taraflı derin bir oyuk/niş vardır. Bu dolapların ve nişlerin içinde, türbenin birçok önemli belgesi, yazması ve sanat eseri bulunurdu. Yapının merkezi boşluğu karedir, köşeleri eğimlidir ve ayrıca dar kemerli girintiler oluşturur. Ana kubbe bu merkezi boşluğu kaplarken, yardımcı yarı kubbeler de olukları kaplar. İçinden dairesel görünür, ancak dışarıdan sekizgen bir plan sunar (Resim 19). ${ }^{33}$

Odanın dikey kesiti, yarım küre kubbesiyle sonuçlanan ve boyalı, yıldız biçiminde şekillerle süslenmiş üç bölgeye ayrılmıştır. Alt bölge odayı saran sırlı karolarla kaplıdır. İkinci bölüm daha büyük kompozisyonlara sahip olup, tümü kemer şeklinde çerçeveli vazolardan filizlenen çiçekli bitkiler panelleri oluşturur. Panellerden biri, çiçekli vazo üstünde, bir ejderha sfenksli madalyon bulundurur. Buna bağlı olarak, bitkilerin dalları içinde, esmâ-i hüsnâdan isimler yazılmıştır. Üçüncü bölümde ise çinili karoların kemer şeklinde bulunduğu görülür. Bütün süslemeler, kırmızı, mavi ve yeşil çiçek tasarımlı boyalı ve yaldızlıdır. Tüm süslemelerde daha önce belirtilen renklerle birlikte pembe, açık mavi, yeşil, leylak ve benzeri renk tonları veren beyaz kurşun kullanılmıştır.

Şah Abbas tarafindan sunulan en büyük Çin porselen koleksiyonunun orada tutulduğu, sıvalı kemerli bu bölüm İsfahan Âli Kapu Sarayı'nın odasına benzer (Resim 20). Ancak burasi estetik olarak daha ince ve porselen eşyaların birlik içinde ve özenle tasarlandığı bir yapıydı. ${ }^{34}$ Çinihâne'nin sıvalı süslemelerinde görülen teknik ve özgün tasarım İsfahan'daki

\footnotetext{
33 Rizvi Kishwar, "Transformations in Early Safavid Architecture:...", 79.

34 Habib Shahbazi Shiran, Ilhama Mammadova, "Archaeology, Art and Architecture "Chini Khaneh" and "Haram Khana", Journal of Multidisciplinary Engineering Science and Technology (JMEST) 5, no.1 (December 2014):129.
} 
benzer örneklerinden daha ayrıntılı ve karmaşıktır. Belki de burada cam ve porselen eşyalar teşhir edileceği için süslenmesine daha fazla özen gösterilmiştir. Çini objeler, çini tabaklar ve diğer mutfak eşyaları gibi cam ve porselen, kâse, tabak vb. eşyalarla kraliyet saraylarında yer alan koleksiyonlara benzer bir koleksiyon sunmaktadır (Resim 21). Fakat bu koleksiyonun büyük bir kısmı 1828 yılında Rusların şehri işgali sırasında St. Petersburg'a götürülmüştür. Eski dönem fotoğraflarından anlaşıldığ kadarı ile bu koleksiyon şimdiye ulaşanlardan çok daha zengindir.

\subsection{Cennetsaray}

Erdebil'deki Şeyh Safiyyüddîn Türbe ve Dergâh1, Şah I. Tahmasb (15241576) döneminde, tarihinin en önemli mekânsal ve işlevsel dönüşümünü gerçekleştirmiştir. Şah Tahmasb bu türbe külliyeye, Cennetsaray denilen, büyük bir eyvanın ardında yükselen, sekizgen planlı ve kubbeli bir yapı inşa ettirdi. Şah İsmail'in inşa ettirdiği Dârülhadis ve Şeyh Safiyyüddîn ile Şah İsmail'in kümbetleriyle birlikte bu bina, türbe külliyesinde açık bir iç avlu meydana getirdi.

Cennetsaray, Dârülhuffâz'ın giriş portaline bitişik türbe avlusunun kuzeydoğu tarafında yer alan büyük bir tuğla yapıdır (Resim 22). Bina, öncelikle merkezi bir eyvandan ve iki ikincil mekândan oluşan büyük bir üçlü cepheden oluşmaktadır. Kuzeydeki sığ eyvan da ahşap bir perde ile çevrelenmiştir ve kuzeyindeki Şehidgâh denilen mezarlığa çıkıntı yapan sı̆̆ bir kubbe ile kaplanmış olup Cennetsaray'a uzanmaktadır. Eyvanın her iki tarafındaki iki küçük oda, salona alternatif erişim sağlar. İçeride Cennetsaray'ın kubbe çapı yaklaşık 21 metredir (Resim 23).

Ek olarak, ikincil hücreler daha derine gömülmüştür. Dârülhuffâz'a bitişik olan, yalnızca halıların ve su kaplarının tutulduğu bir hücredir, diğer hücre ise Cennetsaray'ı bir zamanlar eski Çilehaneye bağlayan bir geçide gider.

Cephenin, F. Sarre'nin 21.yüzyılın başında türbeyi ziyaret ettiğindeki halinden sonra tamir edildiği görülmektedir. Hasarın çoğu kornişlerin üst kısımlarında meydana gelmiş ve yan taraflardaki kitabeler tamamen tahrip olmuştur. Ana eyvan portali de onarılmıştır. Dârülhadis'te olduğu gibi, eyvan, içinde bir kapı bulunan karmaşık bir ahşap panelle çevrelenmiştir. Bu paneller Safevî dönemi, sekizgen kalıplarına göre tasarlanmıştır. 
Cennatsaray'ın avlu cephesi oldukça süslüdür. Bir koridorla asıl salona ulaşılır; ancak sekizgen boşluğa tek erişim buradan değildir. Eski planında, ikisi şimdi kapatılmış olan en az dört giriş daha gösteriliyor. Şehidgâh'ın ön tarafında iki ana giriş hala açıktır. Binanın Çinihâne'den farklı olarak kaymaktaşı taş kaide üzerine yerleştirildiği görülebilir. Girişler, sekizgen planın dışındaki köşelere açılmıştır. Bunlar dışta büyük kemerli oyuklar şeklindedir. Her kemerli oyuk iki bölgeye ayrılır: alt kısımda kapı ve bir pencere bulunur. Üst kısım, uçan payanda ile desteklenir. Şehidgâh tarafinda, bina Dârülhuffâz ve Çinihâne arasındaki geçiş alanına uzanır.

Cennetsaray'ın iç kısmı, yaklaşık 20,5 m çapında, büyük bir sekizgen alandan oluşur. Genişlik, son yıllarda inşa edilmiş büyük, yassı bir kubbe ile örtülmüştür. Geçen yüzyıl boyunca, Cennetsaray on altı mermer sütun tarafından desteklenen düz bir ahşap çatıya sahipti. Bu sırada oda bir cami statüsünü kazandı ve o zamandan beri 'Mescid-i Cennetsaray' olarak anıldı. 16. yüzyıl kaynaklarından Sarîh'ul-mülk burada "gök benzeri bir kubbe" olduğunu belirterek bunu yüce bir yapı olarak nitelendiriyor. ${ }^{35}$ Öte yandan, Safevi dönemi İran eserleri konusunda gözlemlerini yazan Olearius $^{36}$ ve Pietro Della Valle ${ }^{37}$ hatıralarında, Cennetsaray'ın kubbesi hakkında hiçbir şey söylememiş ve zaman zaman bu yapıya "çatısız bir cami" demişlerdir. Ana kubbe ağır hasar gördüğü için, bugün ahşap dolgulu bir kubbe Kaçarlar döneminde inşa edilmiş ve tuğla ve çamurla kaplanmıştır. Tahtadan yapılmış on altı tane kirişi vardır. Çatı, Kaçarlar devrinden sonra da tahrip olmuş ve birçok kez geleneksel tarzda kerpiç tuğla ile tekrar tekrar yapılmıştır ve bu nedenle bu kubbe çok büyük bir kubbe görünümündedir. Mekânın orijinal kubbesi Timurlu kubbelerine daha benzer olmalıydı. Bununla birlikte, kubbe $7 \mathrm{~m}$ kalınlığındaki duvarlara dayanmaktadır. Cennetsaray'ın çevresel bir ayakla taşındığına dair hiçbir kanıt bulunmamakla birlikte, alanın büyük kısmı ana alanı çevreleyen galeriler tarafından kuşatılmaktadır (Resim 19).

35 Rizvi Kishwar, "Transformations in Early Safavid Architecture:...”, 103.

36 Olearuus Adam (d. 1599; ö.1671), Alman yazar, Holstein'in (1635-39) sekreteri Perslere gönderdiği elçi, matematikçi ve kütüphaneci; Safevî Şahı I. Safi'nin (16291642) hükümdarlığı döneminde Rusya ve İran'daki seyahatleri, İran haritasına katkıları ve Sadi'nin Gülistanı'nı Almanca'ya ilk -tam çevirisi ile bilinir. Son erişim: 5 Haziran 2019, http://www.iranicaonline.org/articles/olearius-adam.

37 Della Valle Pretro (d. 1586, ö. 1652), Viaggi'sindeki kayttlarda İstanbul ve Goa arasındaki toprakları anlatan 17. yüzyıl gezginlerinden biri. Son Erişim: 7 Temmuz 2019, http://www.iranicaonline.org/articles/search/keywords:DELLA\%20 VALLE, \%20PIETRO 
Cennetsaray'ın kuzey ve batı duvarlarında, komşu odalara girmek için gizli kemerlerle süslenmiş bazı kapılar vardır. Salonun güney tarafında kubbe ile örtülü küçük, çokgen bir oda vardır. Bu oda sırlı tuğladan yapılmıştır ve bir türbe alanı olarak düşünülmüş veya bazı özel merasimler için kullanılmış olabilir. Batı tarafındaki kapılar, biri Cennetsaray'ı eski Çilehane'ye bağlayacak bir geçit olan küçük odalara çıkar. Fakat bugün geçit çökmüş ve dışarıdan girişi kapatılmıştır. Salonun merkezinde bazı Sûfî ritüelleri için olduğunu tahmin edilen büyük bir dairesel taş bulunmuştur.

Cennetsaray, büyüklüğü ve şekliyle İsfahan' daki Şah Abbas sarayının içine inşa edilen sekizgen tevhidhaneye çok benzer. Burada, Şaha sadık olan sûfîler sabah ve akşam toplanıp dua edecek Safevî ailesinin kalıcılığını över. Kitabe (belki de tek orijinal eyvan olarak kalan) Cennetsaray'in yukarısında bulunup zikir ifadesi olarak Ahzap Suresi 41-43. ayetler yazılmıştır. Cennetsaray, belki de orijinal halvetsarayın (Çilehane'nin işlevi olduğunu düşünürsek) veya daha eski hayır kurumu olan imaretin, üzerine kurulmuştur. Böylece, yeni bina, tasavvuf töreni ve yiyecek dağıtımı gibi sûfî uygulamalarını yerine getirirken, şahların denetimine de açılmıştır. ${ }^{38}$

Erdebil, zaman içinde yalnızca orada yaşayanlar için değil tüm İran ve çevresi için popüler bir yer haline gelmişti. Şah Tahmasb'ın (1524-1576) buraya gömülmesi ve Cennetsaray'ın inşası ile eski sûfî inzivası misyonu yenisiyle değiştirildi. ${ }^{39}$

Bunlara ek olarak Şeyh Safiyyüddîn Dergâhındaki Dârülhadis ve Cennetsaray'ın inşa edilme biçimleri yaratıcı ve ilham vericiydi. Türbe kompleksindeki yeni binalar avludaki belli bir düzen içinde yerleştirildiler. Öyle ki Meşhed, Kum ve İsfahan'da olduğu gibi, Safevi mimarisinde çokça kullanılacak ve mimari karakteristiklerinden biri olacak olan dört eyvan planı Safevi tarihi içinde ilk defa burada kullanıldı.

Cennetsaray, sûfîlerin zikir ve sema ayinleri için inşa edilmiş bir yapıydı. Hadis ilminin öğretildiği ve bu bakımdan Şîa mezhebinin kitabi yorumunu temsil ettiğini düşünebileceğimiz Dârülhadis ile Safevî tarikatı müritlerinin ayinleri için inşa edilmiş ve mezhebin daha batınî yorumunu temsil ettiğini düşünebileceğimiz Cennetsaray'ın, aynı iç avlunun iki

38 Rizvi Kishwar, "Transformations in Early Safavid Architecture: ...", 101-107.

39 Rizvi Kishwar, “Transformations in Early Safavid Architecture...”, 236-237. 
kenarını teşkil edecek şekilde, mekânsal bir diyalog içinde yerleştirilmesi tesadüf değildir. Bu mekânsal ve işlevsel ilişki, Safevîler'in, Şîa'nın batınî/ Alevi yorumu ile kitabî yorumunu harmanlama ve bir arada yaşatma çabasının bir yansıması şeklinde yorumlanabilir. Şah Tahmasb'ın, bu türbe külliyesindeki Dârüllhuffâz yapısının girişine, bütün haram işlerden elini çektiğini ilan etmek üzere yazdırdığı 'tevbe fermanı' da bu bağlamda vurgulanması gereken önemli bir gelişmedir. Bu fermanla Şah Tahmasb, türbenin müdavimi olan Safevî Tarikatı müritlerine, kitabî İslam'ın norm ve kurallarını da dikkate almaları gerektiği mesajını vermek istemiş olabilir. ${ }^{40}$

\section{8. Çilehane (Hankah)}

Avlunun batısında ve Dârülhuffâz'ın karşısında, her ikisi de 14. yüzyılda Sadreddin Musa tarafından yaptırıldığı sanılan iki yapı Çilehane'nin kalıntılarıdır. ${ }^{41}$ Ana avlunun güney ucunda, bu ve türbe avlusu arasındaki küçük avludan erişilen büyük bir çevrilmiş alan vardır. Burası kare şeklindedir ve şu anda çatısızdır, güneydoğu tarafındaki dergâhın avlusuna açılan kemerli pencereleri vardır (Resim 24 a, b). Sarîh'ulmülk ve gezginlerin kayıtlarındaki açıklamalarına göre, bu muhtemelen Sadreddin Musa tarafından yaptırılan yeni Çilehane idi. Şu anda harabe olmasına rağmen, batı dış duvarında ana avluya bakan hala görünen izleri var (burada eskiden bir kapı varmış gibi görünüyor). Bunlar gerçekten Şeyh Safiyyüddîn'in mezar kulesindekilere benzeyen mavi ve yeşil çinilerdir. Sarîh'ul-mülk'e göre bu alan, alt ve üstte kırk odayla çevrili ve Şah Tahmasb'in emriyle yenilenmiş ve döşenmiş, uzun bir kubbe ile örtülmüştür. Yine aynı kaynakta buranın avlunun kuzey tarafına bağlı olduğundan ve aynı zamanda Cennetsaray'a, mutfağa ve Şehidgâh'a bağlanan bir geçide yol açan eski bir Çilehane'den bahsedilmiştir. ${ }^{42}$

\section{9. Dârülhadis (Dârülmütevelli, Dârûsselam)}

Avlunun güneybatı ucunda, yaklaşı $10.50 \mathrm{~m}$ derinliğinde ve $9.5 \mathrm{~m}$ yüksekliğinde toplamda avluda $16.10 \mathrm{~m}$ genişliği kaplayan büyük binadır.

40 Damla Anar Gürkan, "Safevî Şahlarının Baniliği Üzerine Bir Değerlendirme”, 125 126.

$41 \quad$ Habib Shahbazi Shiran, "Archeology and Architectural Aesthetics...", 98.

42 Rizvi Kishwar, "Transformations in Early Safavid Architecture:...”, 94-95. 
Şu anda binaya Dârülmûttavâl denir, ancak burası Sarîh'ul-mülk'de Şah İsmail'in Dârülhadis'i olarak tanımlanır. Dârülhadis'in batı köşesi, Çilehane duvarına (avlu cephesinin bir kısmı) bağlanmıştır (Resim 25).

Daha önce bu, Dârülhuffâz'in yanında devam eden ve sarayı çevreleyen bir duvara tutturulmuştu. Cephe, bir birincil kemerli giriş ve iki yanda iki ikincil olan bir portal gibi tasarlanmıştır. İki yan eyvan ana portale göre daha küçüktür ve ahşap bir kapıdan küęük odalara yönlendirilir. Bu odalara giriş yapmak bugün mümkün değildir. Ancak binanın planı batıdaki odanın birinin Çilehane'ye açıldığını gösterirken, güneyde Haremhane'nin arkasındaki mezarlıkta açıklıklar olabileceğini gösteriyor. Şu anda, bu yan girişler kapalıdır ve güney cephede pencere bulunmaktadır.

Bu Dârülhadis, Sarîh'ul-mülk'de “Şah İsmail'in başlıkları ile süslenmiş yüce bir eyvan" olarak tanımlanır. Eyvan burada "kıble yönünde olduğu için” bir mihrap olarak tanımlanmaktadır. Dış cephenin Cennetsaray'la olan çarpıcı benzerliği, onların birlikte inşa edildiğini akla getiriyor. Şah I. Tahmasb'ın bu yapıyı, bütün külliye için tadilat emri verirken babasının anısına eklettiği düşünülebilir. Daha sonraki belgelerde, Şah I. Tahmasb tarafindan inşa edilen ve bu yapıya atıfta bulunabilecek bir medreseden söz edilmektedir.

Oldukça mütevazı büyüklüğü, binanın işlevsel olmaktan çok sembolik olabileceğini düşündürür. Çünkü eyvan rahat bir şekilde 10-15'ten fazla insanı barındıramayacak kadar küçüktür. Belki de bu alan, özel kimselerin kullanabileceği ve hadis literatürü hakkında ilim yapılması için tasarlanmıştı. ${ }^{43}$

Şah İsmail'in Şeyh Safiyyüddîn Dergâhında hadis ve diğer dini ilimlerin öğretildiği Dârülhadis inşa etmesi ve burada bir vakıf kurması ile külliyede, Safevî şahlarının bâniliği resmen başlamış oldu. 17. yüzyılın ilk çeyreğine kadar devam edecek olan yoğun imar faaliyeti ile bu türbe külliyesi, hanedanın dini ve siyasi eğilimlerindeki değişim ve devamlılıkların gözlenebildiği, şahlığa ait bir mekân haline geldi. ${ }^{44}$

43 Rizvi Kishwar, "Transformations in Early Safavid Architecture:...”, 96-98.

44 Sussan Babaie, "Building on the Past: The Shaping of Safavid Architecture, 150176", Hunt for Paradise: Court Arts of Safavid Iran 1501-1576, ed. Jon Thompson and Sheila R. Canby, (Milan:Skira Editore), 30. 


\section{10. Şehidgâh (Kutsal mezarlık)}

Şehidgâh Şeyh Safiyyüddîn Dergâhının arka bahçesinde sonradan oluşturulmuş özel bir mezar alanıdır. Külliyedeki mimari alanlar esnek tutulmuş olup zamanın ihtiyaçlarına göre değişiyordu. Buna uygun bir örnek, aslen Şeyh Safiyyüddîn'in inzivahanelerinden biri olabilecek “Kümbed-i Şehzade” idi, çünkü burası Darülhuffâz'dan önce yapılmıştı. Külliyenin hayatta kalan en eski yapılarından biriydi. İmparatorluk döneminin başlarında, Şah İsmail ve şehitlerin defnedildiği bir mezarlık alanı oldu (Resim 26, 27). Çinihâne'nin doğu tarafinda, Çaldıran Savaşı (1514) şehitlerinin mezarlarının keşfedilmesiyle sonuçlanan bir hendek açılmış, atların eyerlerinin, silahların ve bazı eşyaların mezarların içine atıldığı görülmüştür (Resim 28). Şehit cenazeleri bir kat sığır veya deve tüylü deriye sarılmıştır. Kazı seviyesinin altında herhangi bir mimari ya da yerleşim elemanı bulunmamış fakat dönemin seramik parçaları bulunmuştur. ${ }^{45}$

\section{Bugüne Ulaşmayan Dergâh Yapıları}

Tarihi kaynaklardan ${ }^{46}$ anlaşıldığı kadarıyla Şeyh Safiyyüddîn Dergâhının bugüne ulaşmayan pek çok hizmet birimi vardır. 16. yüzyılda Şeyh Safiyyüddîn Dergâhında yapılan yenilemeler sırasında Şah Tahmasb'ın vakanüvisi Abdi Bey Şirazi tarafından 1570'te derlenen Sarîh'ul-mülk kayıtları en eski ve detaylı notları verir. Bu belgelere göre dergâhta bulunan ve bugüne ulaşmayan binalar mevcuttur. Dergâhın bekçilerinin evleri ve çok sayıda oda bugüne ulaşmamıştır. Bu odalarda dergâha yapılan

45 Hassan Yousefi, Mohammad Alizadeh Sola, Mahmoud Tavousi, "Reconsidering the Architecture of Shaikh Safi al-Din Ardabili's Shrine: New Findings in Archeological Excavations at Janat Sara Site", Intl. J. Humanities 20, no.1 (2013): 50.

46 Alman bir araştırmacı olan Friedrich Sarre, 1897'de Erdebil'deki Şeyh Safiyyüddîn türbe ve dergâhının mimari ve arkeolojik tarihi üzerine yapılan en kıymetli çalışmalardan birini gerçekleştirerek dergâhın mimarisine ilişkin en eski ve kapsamlı Batı literatürü çalışmasını ortaya koymuştur. Sarre 1897'de binaları fotoğraflayarak bunları editörlüğünde 1901 ile 1910 arasında yayımlamıştır. Sarre'nin bu çalışmaları öncelikle belgesel önemi açısından değerlidir. Buradaki fotoğraflar, dergâhın onarılan ve değiştiren kitabeleri ve düzenlemeleri ile yok olan orijinal durumunu göstermesi ve yirminci yüzyıldan önceki döneme ait olması açısından önemli kayıtlardır. Bkz. Friedrich Sarre ed., Denkmäler Persischer Baukunst: Geschichtliche Untersuchung und Aufnahme Muhammedanischer Backsteinbauten in Vorderasien und Persien: Textband, (Berlin: Wasmuth,1910). 
adakları toplayanlar ikamet etmekteydi. Bunların odaları ve hazneleri yeni çilehanenin karşısındaki eski çilehaneye ve eklerine bitişiktir. Ayrıca sayıları kırktan fazladır.

Başka bir yönetim birimi yapısı olan defterhane bir giriş eşiği (dehliz) ve evden oluşur ki bu ev alçak ve yüksek odalarla çevrelenmiştir. Burası şerbethane ve mahzen/kilerin arasındadır. Mahzen/kiler/depo ve bir kısm1 eski ve Sultan Tahmasb (1524-1576) döneminde satın alınan bazı evlerin bulunduğu üst ve alt odalı depolar mevcuttu. Ayrıca dergâhta bir bando(?) mehter yeri, altında sarnıç bulunurdu. Bunun arkasında hamamın firını ve ahşap dükkân ve bazı evler vardı. Ahşap ambarı ve etrafındaki arazi dışında işlevi bilinmeyen pek çok hücrenin varlığından kaynaklarda bahsedilir. Şah Tahmasb döneminde satın alınan evlerin ve kapalı alanların detaylı listesi ve tapu kayıtları mevcuttur. Fakat bunlardan şu ana ulaşan hiçbir iz veya kalıntı bulunmamaktadır. ${ }^{47}$

Bugün kendisi günümüze gelmemekle birlikte hakkında yazılı kaynaklardan bilgi aldığımız önemli dergâh yapılarından bazıları şunlardır:

\section{1. Kütüphane}

Şeyh Safiyyüddîn'in kütüphanesinin tesisi her ne kadar Safevîler devri gibi gözükmekte ise de daha Şeyh hayatta iken müritlerinin hediyesi ile pek çok kitabın burada toplandığı anlaşılmaktadır. Bu kütüphane, Şah I. Abbas'ın (1587-1629) vakfettiği yeni kitaplar" ${ }^{48}$ ile daha çok büyümüştür. Şah Abbas tarafından vakfedilen bu kitapların üzerinde çoğunlukla kaydını ve hangi yılda vakfedildiğini gösteren notlar mevcuttur. Kütüphane Şah II. Abbas'ın (1642-1666), kütüphane ve Çinihâne'nin bulunduğu kısmı inşa ettirmesiyle tamamlanmıştır.

47 Rizvi Kishwar, “Transformations in Early Safavid Architecture:...”, 250-254.

48 Şah I. Abbas, saraya ait pek çok kitabı İmam Riza〉nın Meşhed`te bulunan türbesi (Âstân-i Kuds-i Rizavî) ile Şeyh Safiyyüddîn'in Erdebil'de bulunan külliyesine vakfetmiştir. Yine, kitapların yanı sıra, pek çok değerli eşya da bu hükümdar tarafından Şeyh Safiyyüddîn'in evkafına vakfedilmiştir. Vakfedilen eşyalar arasında bilhassa çini porselenler bulunmaktadır ki, bu porselenlerde, tıpkı kitaplar gibi "bende-yi Şâh-i vilâyaz "Abbâs vakf ber-âstâne-yi Şâh Safi nemûd" kaydı bulunmaktadır. bkz. Osman G. Özgüdenli, “Şeyh Safîu'd-dîn Erdebîlî’nin Türbesinde Bulunan Kitaplar”, Türklük Araştırmaları Dergisi 10, (2001): 55. 
Geniş bir kitap koleksiyonuna sahip olan Şah I. Abbas, koleksiyonundaki farklı edebi ve ilmi eserleri Erdebil külliyesine; dini kitapları da defalarca ziyaret ettiği ve birtakım yenilikler yaptırarak genişlettiği Meşhed'deki İmam Rıza Külliyesi’ne bağışlamıştır. İç avlunun genişletilmesi, külliyeye dört büyük girişin eklenmesi ve bir kanal açılarak iç avlunun ortasına su getirilmesi, Şah I. Abbas'ın bu külliyede yaptırdığı yenilikler arasındadır. Şah Tahmasb (1524-1576) gibi Şah I. Abbas da Erdebil ve Meşhed'deki türbe külliyelerini çok önemsemiş ve başkentteki imar faaliyetlerinin yanı sıra bu külliyeleri de bâniliğinin merkezine yerleştirmiştir. Sekizinci İmam Ali Rıza ve Safevî hanedanı ve tarikatının atası olan Şeyh Safiyyüddîn'e bağlılıklarını, bu iki türbe külliyesinde yapılan yenilikler ve bağışlar yoluyla göstermek, Safevî şahlarının meşruiyet dayanaklarını izhar etmenin ve güçlendirmenin en etkili yollarından biriydi. ${ }^{49}$

H.1172/M.1758-59 yılında külliyenin mütevellisi Seyyid Muhammed Kâsim Beytarafindan tutulan bir kayda göre, kütüphanede, yazma Kur'ân'lar dışında, 228 cilt kitap ve 32 cilt içerisinde 224 kıta bulunduğu anlaşılmaktadır. Bu kayıtlar haricindeki kayıtlarda ise, 582 cildi Kur'ân ve tefsir, 162 cildi de diğer konularda olmak üzere toplam 844 cilt kitap olduğu belirtilir. Yine, ilgili Osmanlı vakıf kayıtlarında, külliyede korunan ve türbenin son derece önemli vesikalar koleksiyonu ile ilgili bir bilgi bulunmaktadır. Osmanlı vakıf kayıtlarındaki bahsedilen kitapların büyük bir kısmı bugün Leningrad'taki Milli Kütüphane'de bulunmaktadır. Ruslar tarafından Leningrad'a götürülemeyen bazı kitaplar ise bugün Tahran 'da İran Bâstân Müzesi'nde bulunmaktadır. ${ }^{50}$

\section{2. Âli Kapu}

Şeyh Safiyyüddîn Dergâhının mimari tarihi ve gelişimi Safevîler dönemi boyunca devam etmiştir. Bunun en önemli örneklerinden biri Âli Kapu'nın inşasıdır. Şah II. Abbas'ın 1642'de vefatı üzerine dergâh mütevellisi, Nazar Ali Han tarafından büyük Âli Kapu geçidi yaptırılmıştır. ${ }^{51}$

\footnotetext{
49 Damla Anar Gürkan, "Safevî Şahlarının Baniliği Üzerine Bir Değerlendirme”, 136.

50 Osman G. Özgüdenli, “Şeyh Safîu'd-dîn Erdebîlî’nin Türbesinde Bulunan Kitaplar”, 55 .

51 Rizvi Kishwar, “Transformations in Early Safavid Architecture:...”, 241.
} 
Şeyh Safiyyüddîn'in Dergâh1, Erdebil'in merkezinde dairesel bir meydan üzerinde yer almaktadır. Türbeye giriş, üst katları türbe yönetimi tarafindan kullanılan Âli Kapu (11.75 m x 10.5 m) adında büyük bir taş kapı ile yapılır. Kapıdan geçince güzel bir bahçe ve ana dergâhın farklı bölgelerine götüren oluşturduğu yol vardır. Bu giriş yeri, 1642'de Şah II. Abbas'ın tahta çıkışının anısına inşa edilmiştir. Olearius'un 1630'daki Erdebil'in aksonometrik planı ve Abdi Bey'in açıklamalarında mezar kulesinin yanında asılı bir zinciri olan bu kapıya işaret etmektedir (Resim 29). ${ }^{52}$

\section{3. Mutfak}

Bugün Şeyh Safiyyüddîn kompleksinin bahçesinde yapılan kazılarda ortaya çıkan türbe mutfağından kalan en önemli parça mutfağın kemerine yerleştirilmiş kitabeli taştı. Bu, Safevîler'den sonra buradaki kuyuyu kapatmak için ana yerinden başka bir yere devredilmiştir. Bu taş andezitten yapılmış olup üstünde sülüs hatla yazılmış Arapça yazıt vardır. Bu yazıtta fakir insanlar, yetimler ve esirlerin beslenmesinin önemini açıklar. Yazıtın sonunda H. 1001 (M. 1592/1593) tarihi önemli bir kayıttır.

Şeyh Safiyyüddîn Dergâhı hakkında bilgi veren seyyah Tavernier ayrıca bu mutfağ "(Burada) 25 ila 30 büyük soba (ocak) var. Pirinç ve et pişirmek için her bir ocak üzerine yerleştirilen ve daha sonra fakirler arasında dağıtılan veya işçilere verilen büyük bir tencere mevcuttur" şeklinde aktarır. Dergâhta yiyecek dağıtımı için bir sorumlu vardı. Tüm faaliyetlerin ekonomik kaydı vardı. Hollandalı bir sanatçı olan Cornelius, H.1115'te (M. 1606) Erdebil'i ziyaret ettiğinde türbe mutfağı duvarlarına sobalar yerleştirildiğini yazmıştır. İtalyan bir gezgin olan Pieter Delavalle, 35 büyük ocakta yer alan pirinç pişirme kaplarını açıklar ve bir tarafında hamam bulunduğunu söyler. ${ }^{53}$

Mutfağın kuzeyinde kiler, kuzeybatısında ise firın vardır. Şerbethane ise tatlı (helva) pişirmek için bir havuz ve bir bina ile batıya bakan bir portalden oluşur (Resim 30). Ondan sonra ek odalar mevcuttur (Resim 31).

52 Rizvi Kishwar, “Transformations in Early Safavid Architecture... ”, 107-108.

53 Hassan Yousefi, Mohammad Alizadeh Sola, Mahmoud Tavousi, "Reconsidering the Architecture of Shaikh Safi al-Din Ardabili’s Shrine...", 57. 


\section{4. Hamam}

Bütün dergâhlarda olduğu gibi Şeyh Safiyyüddîn Dergâhında hamam mevcuttur. Hamam bir tarafta türbenin ön avlusu, bir tarafta mutfağın ve firının bulunduğu cadde ile çevrelenmiştir. Hamamın diğer yönlerinde kiler ve bando sahnesi (nakkarhane) bulunur.

Özellikle M. 14. yüzyılda Şeyh Safiyyüddîn'in Çilehanesinin hamam, mutfak ve diğer olanaklarla donatıldığı açıktır. Bunlar muhtemelen özellikle Şah I. Abbas tarafından büyük ölçüde iyileştirildi ve genişletildi. Kazılarda keşfedilen mekânlardan olan, mutfağın doğu kısmında iç kil kanallarının bir hamam kapısı olması muhtemeldir. Diğer yapılar arasında küçük havuz, kuyu ve çinilerle süslenmiş sıcak odanın bir kısmı görülür. Su kanalı, 1sitma sistemi ve kil kanallı su iletim ve tahliye sistemi bulunur. ${ }^{54}$ Başka bir su yapısı olan su değirmeni Şeyh Safiyyüddîn'in türbesinin yakınındadır

\section{Safevî Şahlarının Şeyh Safiyyüddîn Dergâhı ile Bânilik İlişkileri}

Safevî şahları yukarıda belirtildiği üzere Şah İsmail'den başlayarak hanedanlığın sona ermesine kadar Şeyh Safiyyüddîn Dergâhına himayelerini sürdürmüştür. Şahlar söz konusu külliyede tamir ve yenilikler yapmanın yanı sıra buralara çeşitli değerli eşyalar, mülk gelirleri ve para da vakfediyorlard1.

Özellikle Şeyh Safiyyüddîn Dergâhını diğer var olan türbe külliyelerini himaye etmedeki ısrarın bir sebebi, bunların yer aldığ 1 şehirlerin sürekli depremlerle yıkılması, iklimin kurak olması ve tuğla-kerpiç ağılıklı yapı malzemesinin dayanıksızlığı sonucunda yapıların sürekli zarar görmesi ve bakıma, tamire ihtiyaç duymasıdır. Fakat Safevîler'in, Ehl-i Beyt İmamları ve İmamzade türbeleri ile Erdebil' deki, hanedanın atası ve Safevî tarikatının âsitânesi olan Şeyh Safiyyüddîn Türbesi'ni himaye etme konusundaki bu belirgin isteklerinin asıl sebebi, onların dini inanç ve kimlikleriyle doğrudan bağlantılıymış gibi gözüküyor. Hâkim kanının aksine, Safevî hanedanının Alevi inanç ve pratiklerine olan temayülü, Şah İsmail dönemiyle sınırlı

54 Hassan Yousefi, Mohammad Alizadeh Sola, Mahmoud Tavousi, "Reconsidering the Architecture of Shaikh Safi al-Din Ardabili’s Shrine...", 58. 
değildir. Özellikle Şah Tahmasb döneminden itibaren, söz konusu inanç ve pratiklerden gözle görülür bir uzaklaşma olmasına ve on iki imam Şiîliğinin kitabi yorumunun ağırlık kazanmasına rağmen Safevîler'in, özellikle 14. ve 15. asırlarda tarikat inanç ve erkanında ağırlık kazanan Alevi/batıni temayüllerini, Safevî tarikatının mirası ve hatırası olarak, hanedanın tarihi boyunca korunmuş ve sembolik olarak devam ettirilmiştir. ${ }^{55}$

Böylece, Safevî tarikatının kurucusunun ve manevi atasının türbesi etrafında gelişen bu külliyede, Safevî şahlarının bâniliği başlamış oldu ve 17. yüzyılın ilk çeyreğine kadar devam edecek olan yoğun imar faaliyeti ile bu türbe külliyesi, hanedanın dini ve siyasi eğilimlerindeki değişim ve devamlılıkların da açıkça gözlenebildiği, şahlığa ait bir mekân haline geldi. ${ }^{56}$

Şüphesiz, Şeyh Safiyyüddîn'in külliyesi şahın himayesindeki tek yap1 değildi; ancak külliye şahlı̆̆ın temsil ettiği bir ölçek ve tarzdaydı. Şahlar atalarının türbe ve dergâhında Safevî otoritesinin yeniden yapılandırılmış şu mesajlarını sergiledi: bir sufînin tevazuu, bir şeyhin karizması ve bir şahın gücü. ${ }^{57}$

Safevî hanedanının bâniliğinin merkezinde bulunan söz konusu türbe külliyeleri, Moğol istilasını izleyen dönemde birbirini takip eden hanedanların, yerel seyyid ve eşrafın himayesinde büyüyüp genişleyerek birer ziyaret merkezi haline gelmişlerdir. Safevîler'den önce, İlhanlı ve Timuri hanedanları mensupları, yüksek dereceli bürokratlar, alimler ve tüccarları da içeren pek çok grup, bu türbe külliyelerinde binalar inşa etmiş, tamir ve yenilikler yapmış, vakıflar kurmuş ve buralara çeşitli bağışlar yapmıştır. Lisa Golombek'in “Tanrı'nın küçük şehirleri” tanımını önerdiği bu türbe külliyeleri, Moğol sonrası dönemde bânilik ve vakıf faaliyetlerinin en önde gelen merkezlerini teşkil ediyordu. Türbelerin etrafında büyüyüp gelişen bu çok işlevli yapı topluluklarının İran dışındaki diğer örneklerini, Osmanlı ve Memlük hakimiyeti altındaki şehirlerde de görmek mümkündü. ${ }^{58}$ Özetle bu külliyelerin kendilerini çevreleyen kent

\footnotetext{
55 Damla Anar Gürkan, "Safevî Şahlarının Baniliği Üzerine Bir Değerlendirme”, 122.

56 Sussan Babaie, "Building on the Past: The Shaping of Safavid Architecture, 1501- 76", 28.

57 Rizvi Kishwar, “Transformations in Early Safavid Architecture: ...”, 241.

58 Damla Anar Gürkan, "Safevî Şahlarının Baniliği Üzerine Bir Değerlendirme”, 124.
} 
dokusu ile uyumlu ve görsel diyalog halinde olmaları Safevi dönemine mahsus bir özellik değildir; fakat bu özellik, Safevî mimarisinin en dikkat çekici ve ayırıcı hususiyetlerinden birini teşkil etmektedir.

\section{Sonuç}

Şeyh Safiyyüddîn Dergâhı, tarih boyunca Safevî şahları tarafından himaye edilerek genişleyip, korunmuştur. Zamanla onların güçleri ve etkileri arttıkça, dergâhın bilinirliği ve tanınması ile gücü de artmıştır. 1501 yılında Şeyh İsmail b. Haydar (d. 1524) yani Şah İsmail başkent yaptığı Tebriz'de Safevî devletini kurup kendini şah ilan etmesiyle dergâhın geleceğini şekillendirmiştir.

Safevî devletinin kurumsallaşma ve değişim ilkeleri/değerleri Şah İsmail döneminden itibaren önemli bir dini merkez olan Şeyh Safiyyüddîn Dergâhı'na doğrudan aktarılmıştır. Bir anlamda Safevi tarikatı Safeviler'in asıl kurucu nüvesi olmuştur. Safevi tarihi boyunca tıpkı dini uygulamanın tasavvuftan ortodoksiye doğru kaydırılması gibi, türbenin mimari merkezi Şeyh mezarından Şah'ın yeni yapılarına doğru yeniden düzenlenmiştir. Dergâhın eski binalarının heterojen ve zengin yapısı, zaman içinde kazanılan yeni mimari üslup ve düzen ile uyum içinde kurgulanmıştır. Zamanla dergâh mimarisi ve düzeninde bilhassa simetri ile bütünleşme estetiği göze çarpmaya başlamıştır. Öyle ki İsfahan'daki yönetim yapıları ile Erdebil'deki bu dergâhın çeşitli sosyal ve sanatsal yapı türleri mimari düzen ve kurgularında dikkat çekici bir benzerlik göstermiştir.

Aslında Şeyh Safiyyüddîn Dergâhı'nın neredeyse her bölümü, Şeyh Safiyüddin türbesi merkezindeki tasavvuf temelli inançlar, kentsel yenileşme, fiziksel genişleme, ekonomik özerklik, şahlık himayesi ve halkın iltifatı gibi farklı dinamiklerle mimari gelişimlerini sürdürüp değiştirmiştir. Bu dini merkezin uzun ömürlülüğünün belki de en önemli kanıtı halktan elitlere kadar toplumun tüm katmanlarının buradan sağladığı olanaklara olan bağlılıklarıdır. Yabancı gezginlerin türbe konusunda geride bıraktığ1 kayıtlar, dergâhın yönetimsel ve fiziksel anlamda toplumun farklı katmanları ile etkileşime girdiği, enerjik ve dinamik bir kamusal alana sahip olduğu yönündedir. Dergâhın mimari düzenlemesinin içine yerleştirilmiş olan ritüeller eski geleneklerin devamını ve yenilerinin icadı ortaya çıkarmıştır. 
Bugün Şeyh Safiyyüddîn Dergâh ve Türbesinin durumu ona yeni bir bakış açısıyla bu mimari organizasyonu yeniden düşünmeyi gerektirmektedir. Safevî dini mimarisi üzerinde yapılacak derin çalışmalar İslam sanatının önemli bir dönemini ve tasavvuf sanat ilişkisini hakkıyla anlamaya yol açacaktır. Bu türbe kompleksinin, İslam coğrafyasının farklı merkezlerinde ortaya çıkan bu tür diğer külliyeler ortak birçok yönü vardır. Bununla birlikte bu dergâh ve onun geleneği Safevî İran'ın güçlü ve yetkin komşuları olan hem batısındaki Osmanlı hem de doğusundaki Babür imparatorluklarının çağdaş külliyeleri ile karşılaştırılarak analiz edilmeyi beklemektedir.

\section{Kaynakça}

Anar Gürkan, A. Damla. "Safevî Şahlarının Baniliği Üzerine Bir Değerlendirme", Iran Çalışmaları Dergisi 1, no. 1 (2017): 117-143.

Babaie Sussan. "Building on the Past: The Shaping of Safavid Architecture, 1501-76", Hunt for Paradise: Court Arts of Safavid Iran 1501-1576, ed. Jon Thompson and Sheila R. Canby, 26-47. Milan:Skira Editore, 2003.

Blair, Sheila. "Texts, Inscriptions and the Ardabil Carpets". In Iran and Iranian Studies: Essays in honor of Iraj Afshar, ed. K. Eslami, Princeton: Zagros Press, 1998, 137-47.

Çelenk, Mehmet. "16 ve 17. Yüzylllarda Safevî Şiîliği." Doktora Tezi, Uludağ Üniversitesi, 2005.

Golombek, Lisa and Wilber, Donald. The Timurid Architecture of Iran and Turan. Princeton, 1988.

Golombek, Lisa. "The Cult of Saints and Shrine Architecture in the Fourteenth Century" in Near Eastern Numismatic, Iconography, Epigraphy and History, ed. D. K. Kouymjian, 419- 430. Beirut, 1974.

Gronke, Monika. Derwische im Vorhof der Macht: Sozial-und Wirtschafttsgeschichte Nordwestirans im 13. und 14. Jahrhundert. Stuttgart: Franz Steiner, 1993.

Hillenbrand, Robert. Safavid Art and Architecture. London, 1998.

ICHHTO, Sheikh Safi Al-Din Khanegah And Shrine Ensemble In Ardabil Nomination Report. UNESCO World Heritage Convention Nomination of Properties for Inclusion on the World Heritage List, Tehran, 2009. 
Kara, Mustafa. "Tekke", Türkiye Diyanet Vakfi İslam Ansiklopedisi, 40: 368-370, İstanbul: TDV Yayınları 2011.

Kishwar, Rizvi. "Transformations in Early Safavid Architecture: The Shrine of Shaykh Safiyyüddîn al-din Ishaq Ardabili in Iran (1501-1629)", $\mathrm{PhD}$ diss., University of Harvard, 2000.

Kishwar, Rizvi. "The Imperial Setting: Shah Abbas at the Safavid Shrine of Shaykh Safiyyüddîn in Ardabil." In Safavid Art and Architecture. Edited by Sheila R. Canby, 9-15. London: The British Museum Press, 2002.

Kishwar, Rizvi. The Safavid Dynastic Shrine: Architecture, Religion and Power in Early Modern Iran. New York, 2011.

Kumkale Açıkgöz, E, Rouyandozagh, Y. "Selective Re-Creation Of Remembrances: The Case Of Sheikh Safi Al-Din Khānegāh And Shrine Ensemble in Ardabil, Iran". İdealkent 7 (2016): 402-426.

Musal1, Namiq. "Şeyh Safiyyüddîn Velâyetnâmesi: Tahkiki ve Transkripsiyonu", Türk Kültürü ve Hacı Bektaşı Veli Araştırmaları Dergisi 84, (Kış, 2017): 163-193.

Morgan, J. De. Mission scientifique en Perse. Tome troisième. Parties II à IV, Etudes géologiques. Paléontologie I, Paris: 1895.

Öngören, Reşad. "Safevîyye”, Türkiye Diyanet Vakfi İslam Ansiklopedisi, 35: 460-462, İstanbul: TDV Yayınlar1, 2008.

Özgüdenli, Osman G. "Şeyh Safîu'd-dîn Erdebîlî’nin Türbesinde Bulunan Kitaplar”. Türklük Araştırmaları Dergisi 10 (2001), 43-56.

Sarre, Friedrich, ed., Denkmäler persischer Baukunst: geschichtliche Untersuchung und Aufnahme muhammedanischer Backsteinbauten in Vorderasien und Persien (Tafelband). Berlin: Wasmuth,1901.

Sarre, Friedrich, ed., Denkmäler persischer Baukunst: geschichtliche Untersuchung und Aufnahme muhammedanischer Backsteinbauten in Vorderasien und Persien: Textband. Berlin: Wasmuth,1910.

Pope, Arthur Upham. Chinese Porcelains from the Ardebil Shrine. New York, 1956.

Shiran, Habib Shahbazi. "Archeology and Architectural Aesthetics of Jannat-sara Mosque and Haramkhana, two buildings located within the monument Sheikh Safiyyüddîn al-din Ardabili, Ardabil world heritage, in Iran". Research Journal of Recent Sciences 4, no. 9, (2015): 97-106. 
Shiran, Habib Shahbazi, Mammadova, Ilhama. "Archaeology, Art and Architecture Chini Khaneh and Haram Khana". Journal of Multidisciplinary Engineering Science and Technology (JMEST) 1, no. 5, (2014): 129-134.

Şah, Serap. “Safvetü's-Safầ 'da Safiyyüddîn-i Erdebîlî̀nin Hayatı, Tasavvufì Görüşleri ve Menkıbeleri”. Doktora Tezi, Marmara Üniversitesi, 2007.

Tanman, Baha. "Âsitâne”, Türkiye Diyanet Vakfı İslam Ansiklopedisi, 3 : 485-487, TDV Yay., İstanbul, 1991.

Tanman, Baha. "Dârülkurra". Türkiye Diyanet Vakfi İslam Ansiklopedisi, 8: 545-548, TDV Yay., İstanbul, 1993.

Walther, Hinz. Uzun Hasan ve Şeyh Cüneyd. Ankara: Türk Tarih Kurumu Bas., 1992.

Werner, Christoph Udo. "Ein vaqf für meine Töchter, Hātūn Ğān Bljgum und die Qarā Quyūnlū Stiftungen zur, Blauen Moschee“ in Tabriz”, Yıldız, Leyla (Çev.). "Kızlarım İçin Bir Vakıf Hatun Can Begüm ve Tebriz'de Gök Mescid'in Karakoyunlu Vakıfları", Marmara Türkiyat Araştırmaları Dergisi 2, no. 2, (Sonbahar 2015): 251-266.

Yousefi, Hassan, Sola, Mohammad Alizadeh, Tavousi, Mahmoud. "Reconsidering the Architecture of Shaikh Safiyyüddîn al-Din Ardabili's Shrine: New Findings in Archeological Excavations at Janat Sara Site", Intl. J. Humanities 20, no. 1, (2013): 49-67.

Zarinebaf-Shahr, Fariba. "Economic Activities of Safavid Women in the Shrine-City of Ardabil”, Iranian Studies 31, no. 2, (1998): 247-261.

\section{Internet Kaynakları}

“Olerius Adam”, Encyclopaedia Iranica, 7 Nisan 2008, Son erişim: 5 Haziran 2019.

http://www.iranicaonline.org/articles/olearius-adam

"Della Valle Pietro", Encyclopaedia Iranica, 15 Aralık 1994, Son erişim: 7 Temmuz 2019, http://www.iranicaonline.org/articles/search/ keywords:DELLA\%20VALLE,\%20PIETRO

“Şahnişin”, Türk Dil Kurumu Sözlükleri, Son erişim: 15 Temmuz 2019, https://sozluk.gov.tr/?kelime=\%C5\%9EAHN $\% \mathrm{C} 4 \% \mathrm{~B} 0 \% \mathrm{C} 5 \% 9 \mathrm{E} \% \mathrm{C} 4 \% \mathrm{~B}$ $0 \mathrm{~N}$ 


\section{Resimler}

Resim 1: Şeyh Safiyyüddîn tarikatının dünyadaki yayıldığı merkezler

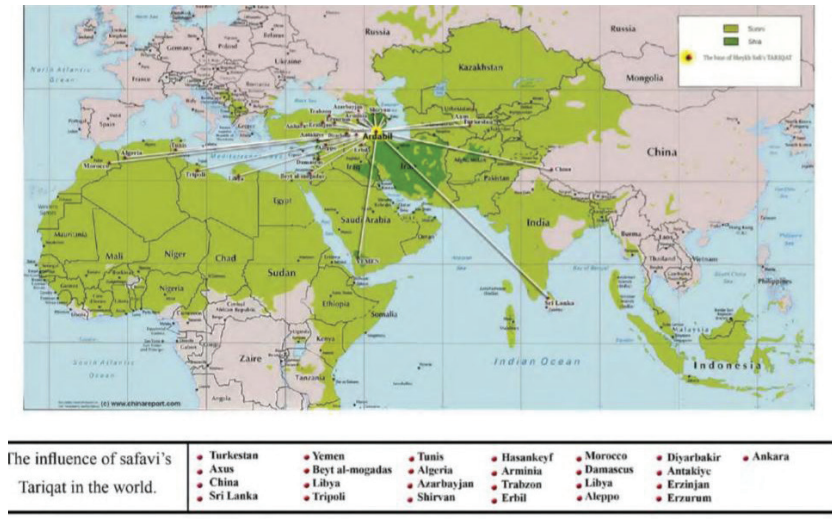

Kaynak: ICHHTO, Sheikh Safi Al-Din Khanegah And Shrine Ensemble In Ardabil Nomination Report. UNESCO World Heritage Convention Nomination of Properties for Inclusion on the World Heritage List, Tehran, 2009, 23.

Resim 2: Frederic Sarre'nin çizdiği Şeyh Safiyyüddîn Türbe ve Dergâhı planı

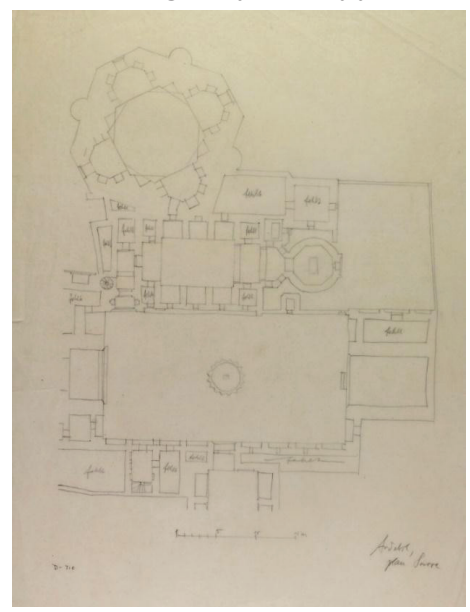

Kaynak: Friedrich Sarre ed., Denkmäler Persischer Baukunst: Geschichtliche Untersuchung und Aufnahme Muhammedanischer Backsteinbauten in Vorderasien und Persien: Textband, Berlin: Wasmuth, 1910, 35 
Resim 3: Şeyh Safiyyüddîn Türbe ve Dergâh planı

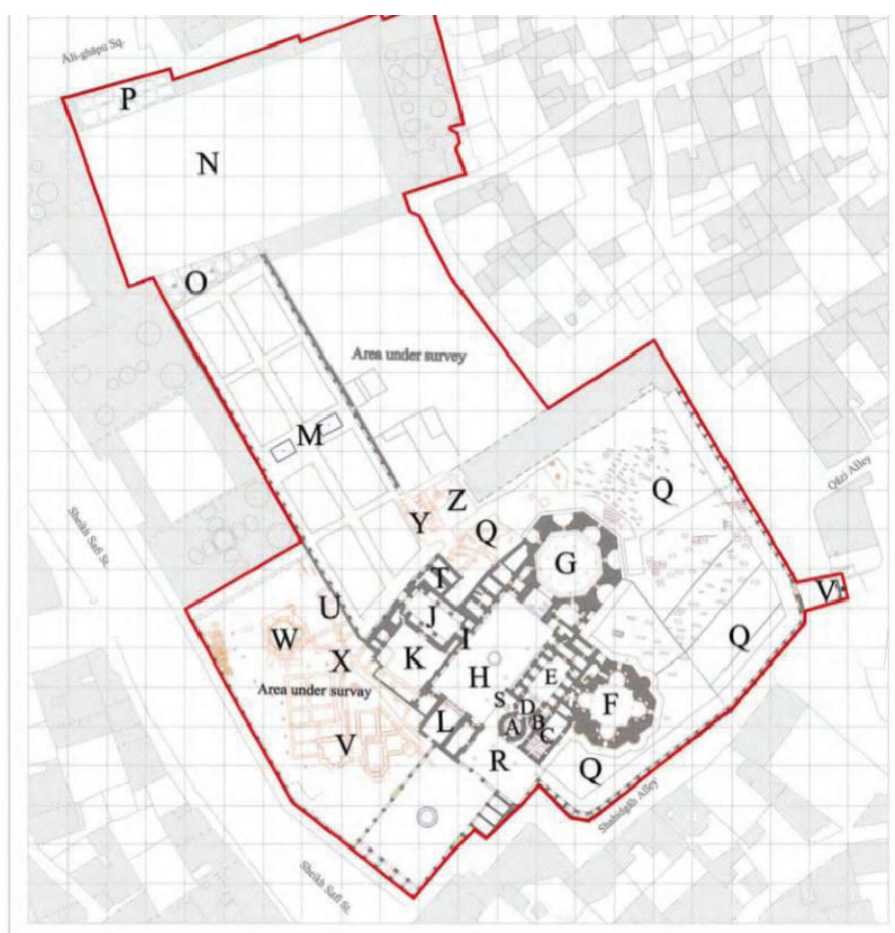

Kaynak: ICHHTO, Sheikh Safi Al-Din Khanegah And Shrine Ensemble In Ardabil Nomination Report. UNESCO World Heritage Convention Nomination of Properties for Inclusion on the World Heritage List, Tehran, 2009, 35. ( A:Şeyh Safiyyüddîn Türbesi (Allah Allah kubbesi), B: Şah İsmail Türbesi, C: Muhyiddin Muhammed Türbesi (Haremhane), D: Şahnişin, E: Dârülhuffaz (Kandilhane), F: Çinihâne, G: Cennetsaray, H: Sahn, Meydan, I: Şah Abbas kapısı, J: İç avlu, K: Yeni çilehane, L: Dârülhadis, M: Bahçe, N: Meydan, O: İkinci kapı, P: Ana kapı (Darvâzeh), Q: Şehidgâh, R: Mezar avlusu, S: Şah İsmail'in annesinin türbesi, T: Bahçe avlusunun güney hücreleri, U: Kuzey hücreler, V: Seyyid Şeyh Şah b. Hoca Hasan Bey Safevî evi, W:Şerbethane, X: 1995 'ten sonra kazıda çıkan topraklar, Y: 2006'dan sonra keşfedilen hamam, Z: 2006'dan sonra keşfedilen aşhane). 
Resim 4: Şeyh Safiyyüddîn Mezar Kulesi/Türbesi

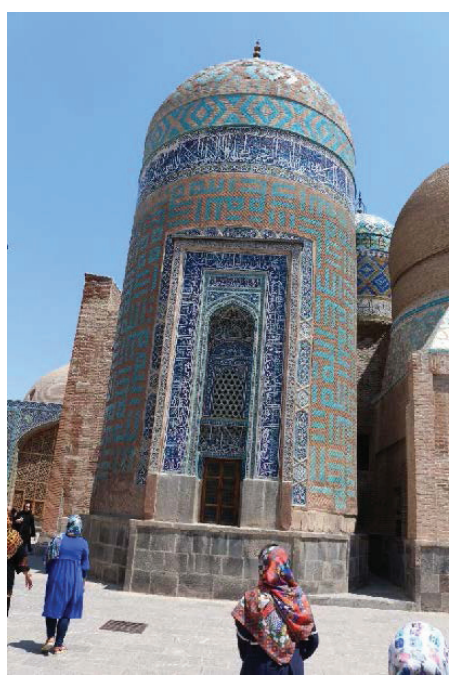

(Kaynağı belirtilmeyen fotoğraflar yazara aittir)

Resim 5: Şeyh Safiyyüddîn Türbesi

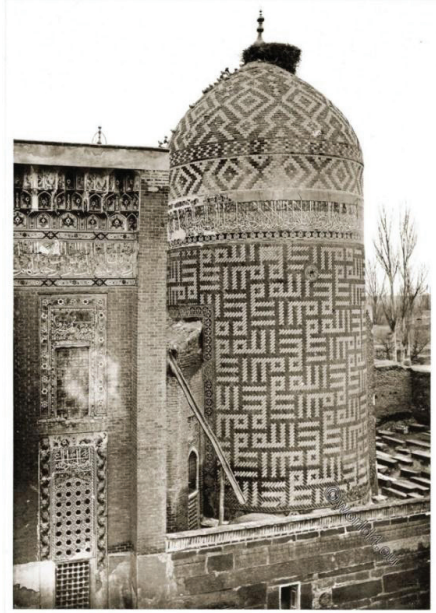

Kaynak: Friedrich Sarre, ed., Denkmäler Persischer Baukunst: Geschichtliche Untersuchung und Aufnahme Muhammedanischer Backsteinbauten in Vorderasien und Persien (Tafelband), Berlin: Wasmuth, 1901, 81. 
Resim 6: Şeyh Safiyyüddîn Türbesi kapısı

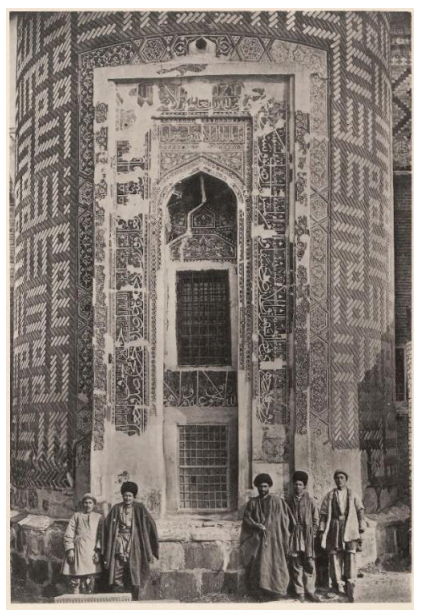

Kaynak: Friedrich Sarre, ed., Denkmäler persischer Baukunst: geschichtliche Untersuchung und Aufnahme muhammedanischer Backsteinbauten in Vorderasien und Persien (Tafelband) Berlin: Wasmuth, 1901, 82.

Resim 7: Şeyh Safiyyüddîn Türbesi sandukası

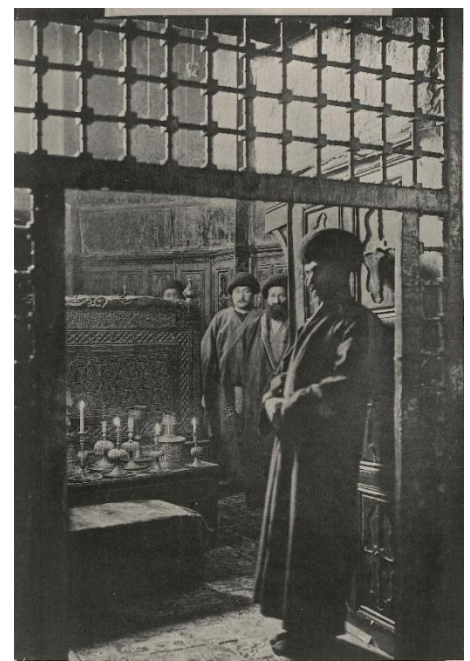

Kaynak: Friedrich Sarre, ed., Denkmäler persischer Baukunst: geschichtliche Untersuchung und Aufnahme muhammedanischer Backsteinbauten in Vorderasien und Persien (Tafelband) Berlin: Wasmuth, 1901, 103. 
Resim 8: Şeyh Safiyyüddîn sandukası

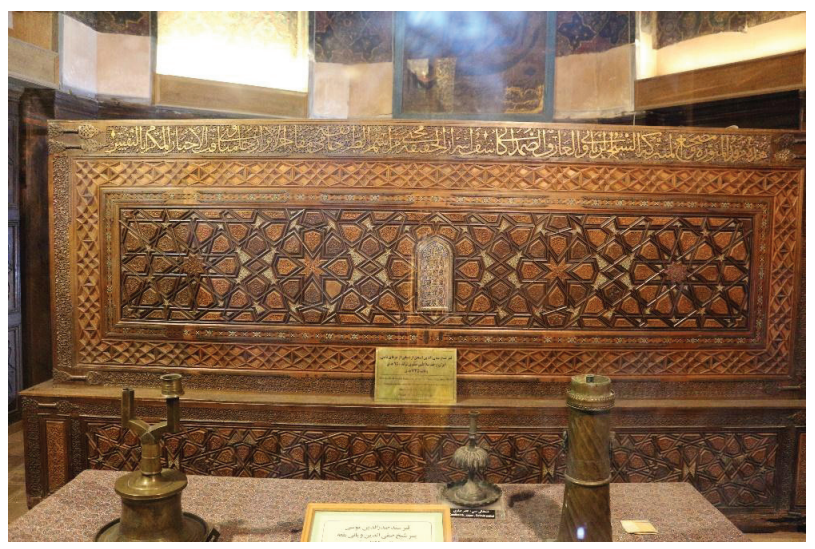

Resim 9 a: Şah İsmail Türbesi kubbe dıştan

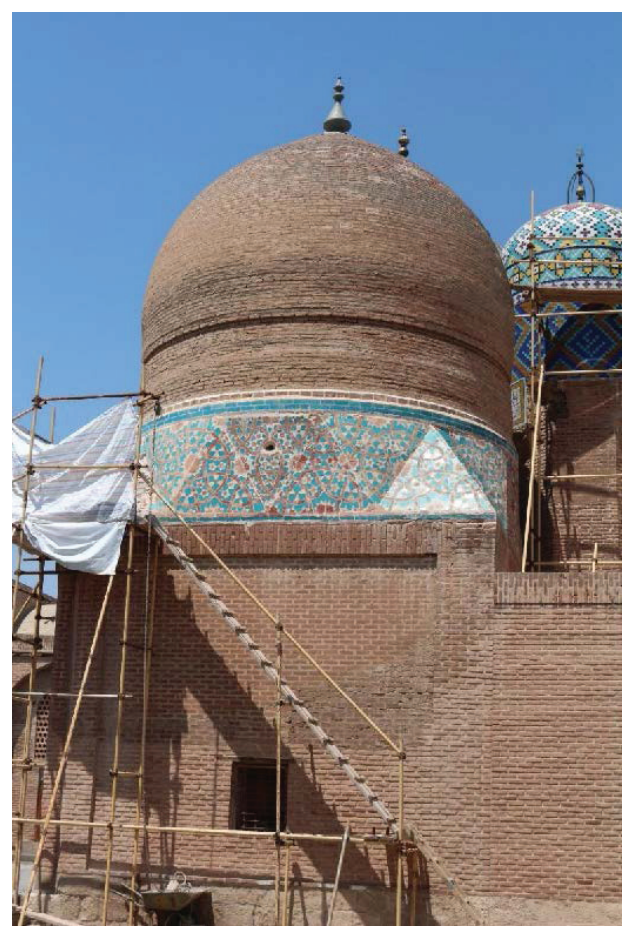


Resim 9 b: Şah İsmail Türbesi sandukası

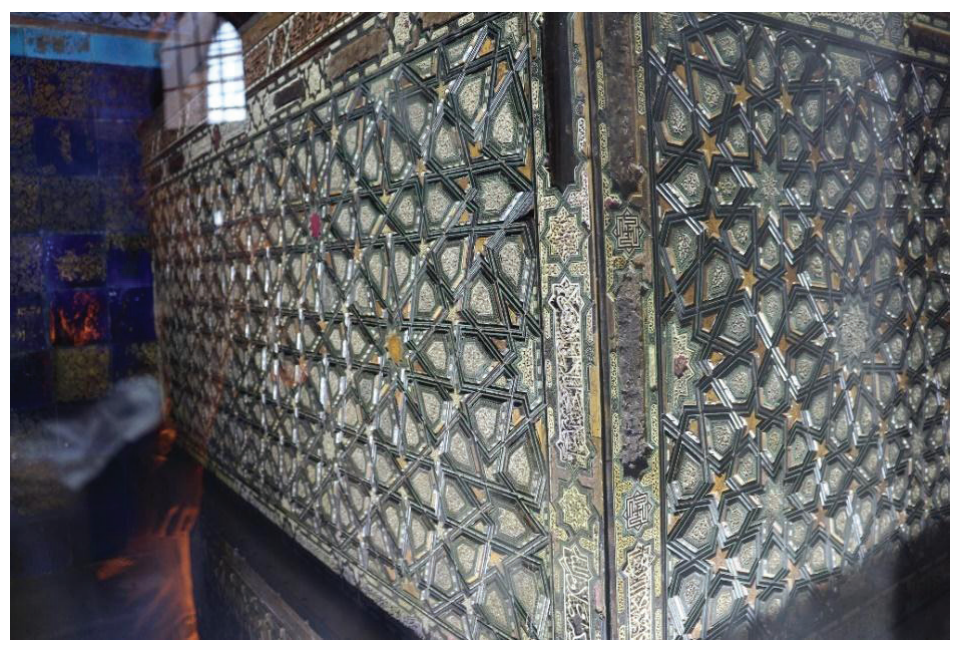

Resim 10: Haremhane'deki sandukalarından biri

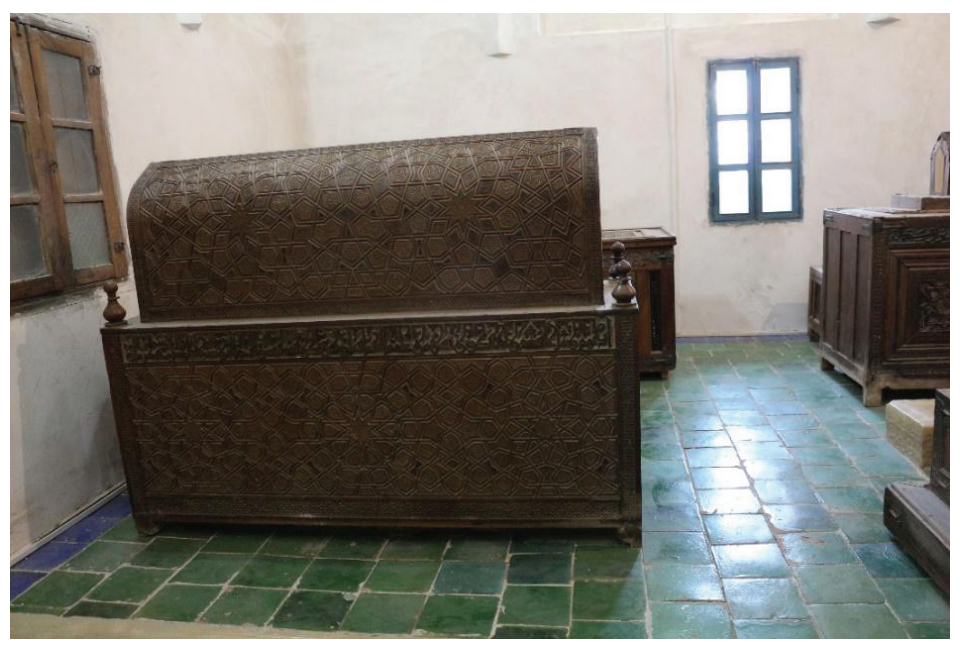


Resim 11: Haremhane kubbe detay1

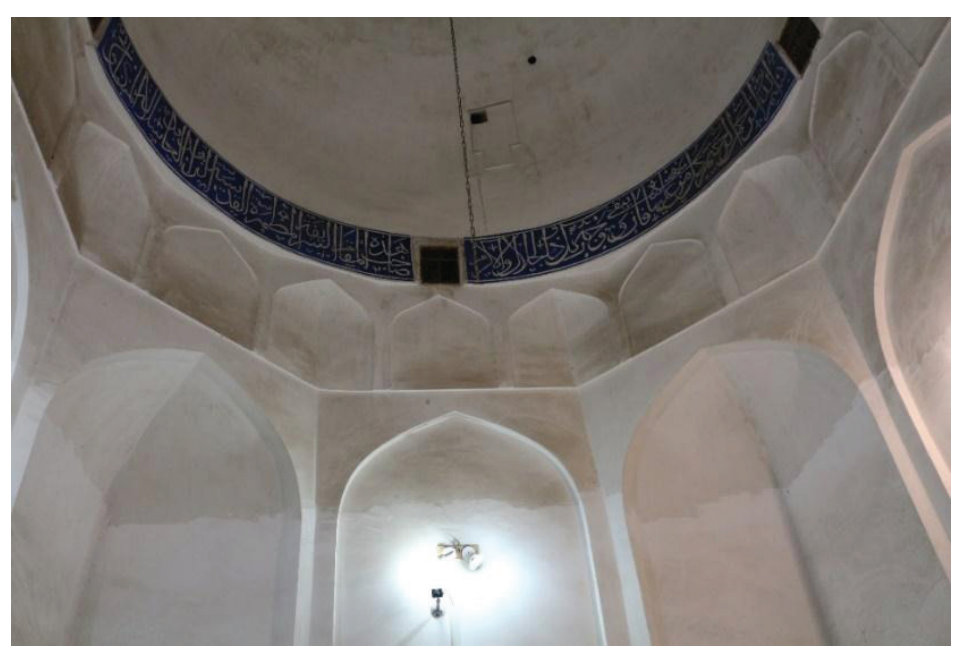

Resim 12a: Şahnişin içten

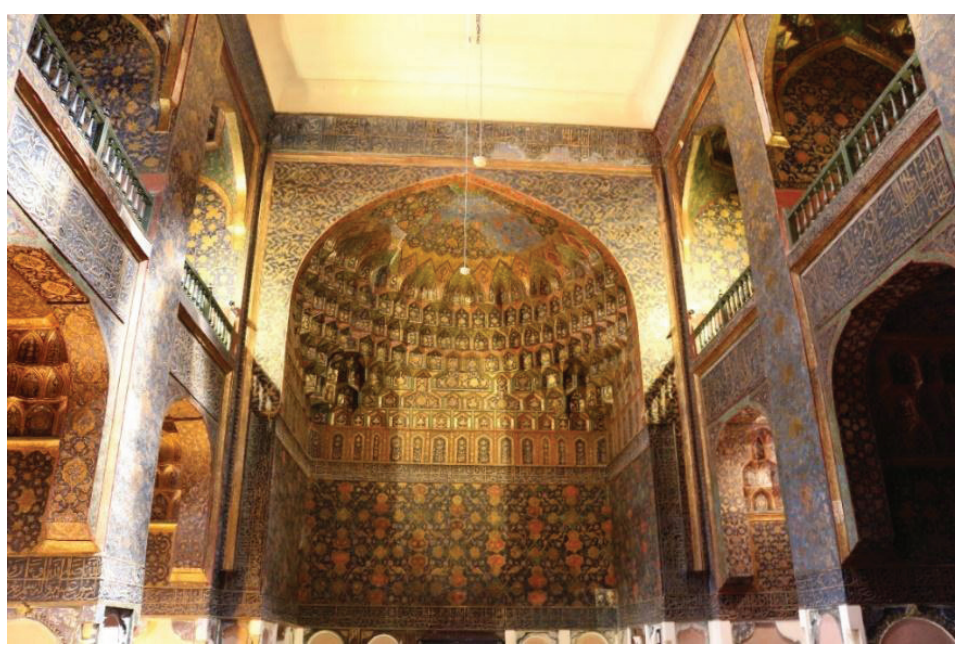


Resim 12 b: Şahnişin içten çizimi

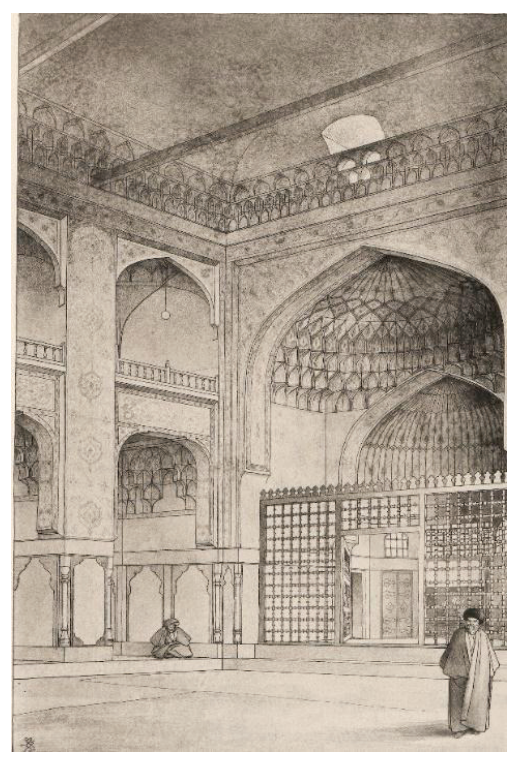

Kaynak: Friedrich, Sarre, ed., Denkmäler Persischer Baukunst: Geschichtliche Untersuchung und Aufnahme Muhammedanischer Backsteinbauten in

Vorderasien und Persien (Tafelband) Berlin: Wasmuth, 1901, 102.

Resim 13: Dârülhuffâz ile Şeyh Safiyyüddîn Türbesi arasında yer alan Şahnişin'in diştan görünüşü

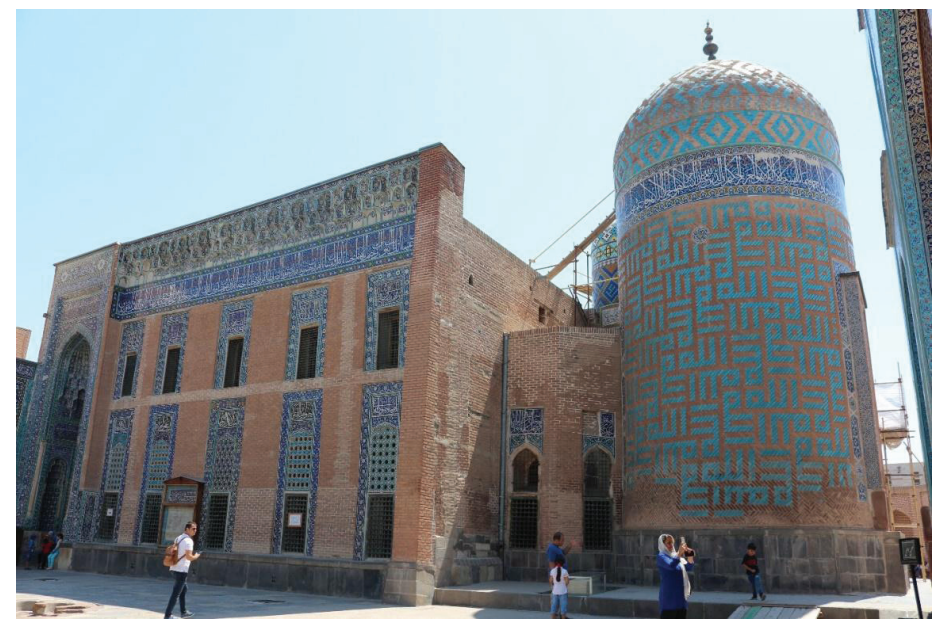




\section{Resim 14: Dârülhuffâz diştan}

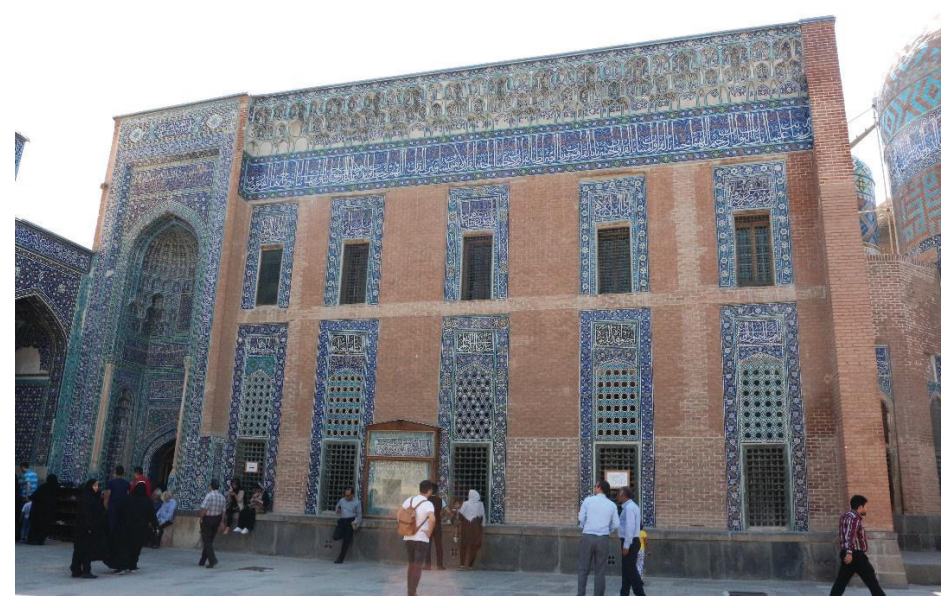

Resim 15: Dârülhuffâz diştan

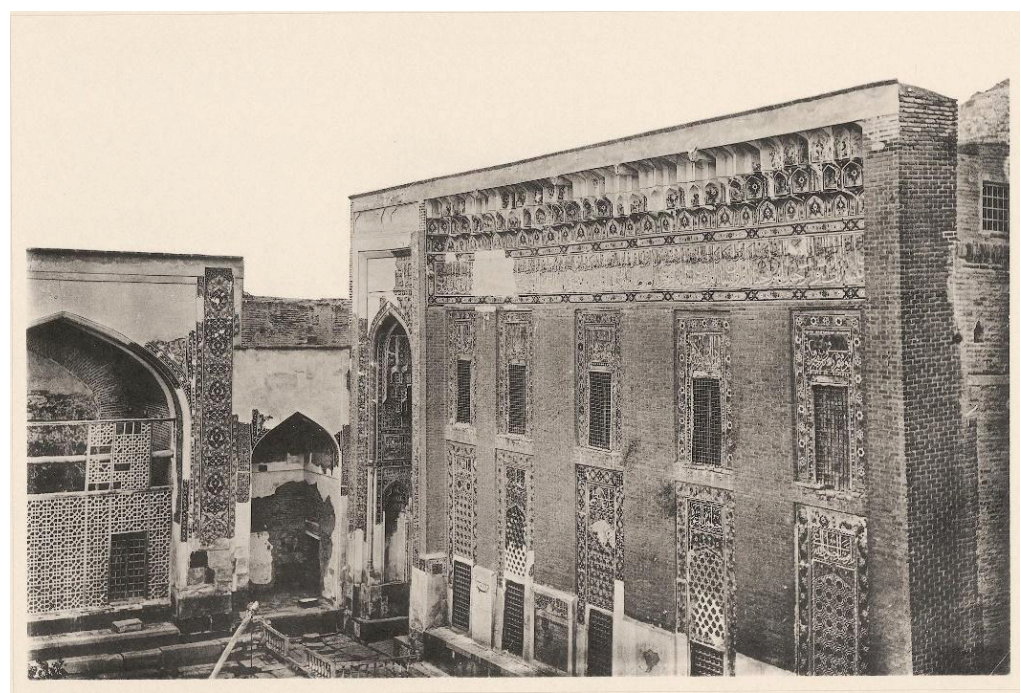

Kaynak: Friedrich, Sarre, ed., Denkmäler Persischer Baukunst: Geschichtliche

Untersuchung und Aufnahme Muhammedanischer Backsteinbauten in Vorderasien und Persien (Tafelband) Berlin: Wasmuth, 80. 
Resim 16 a: Çinihâne

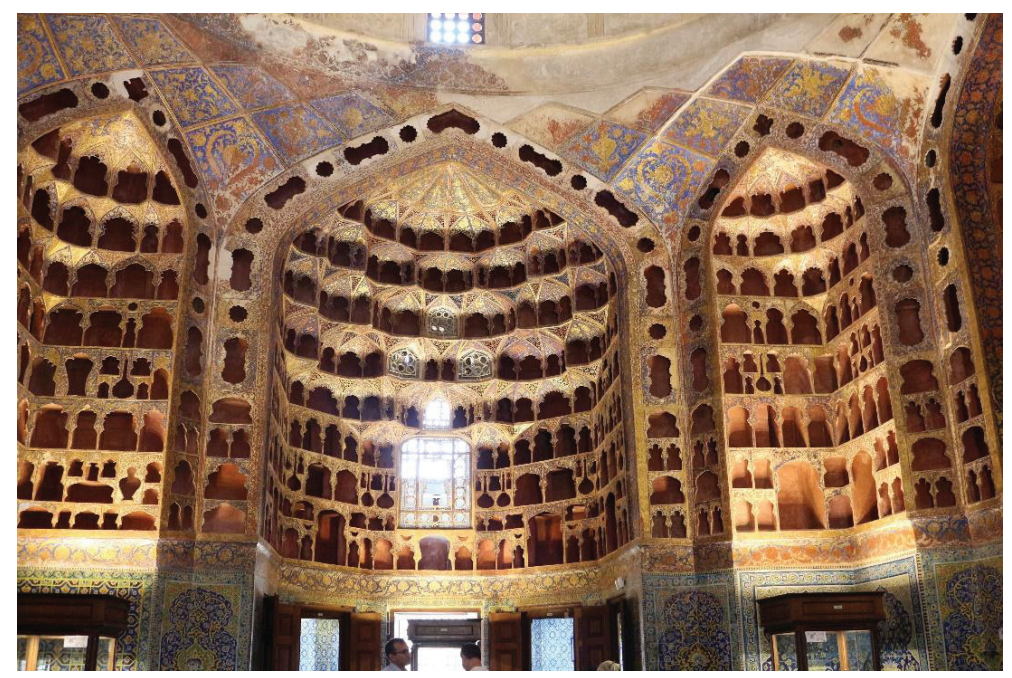

Resim 16 b: Çinihâne detay

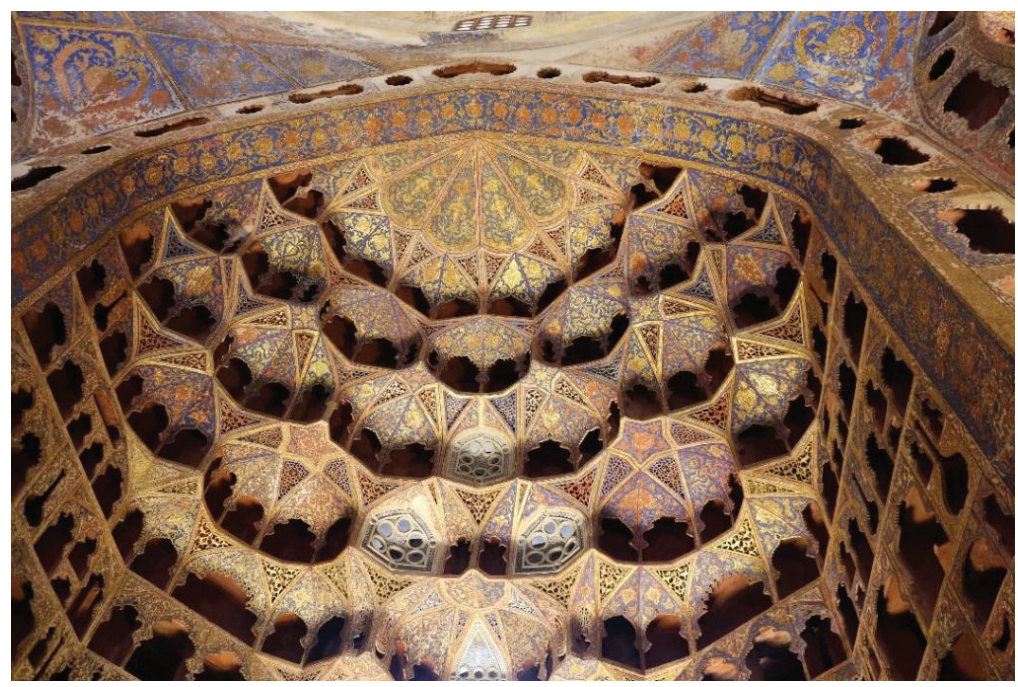




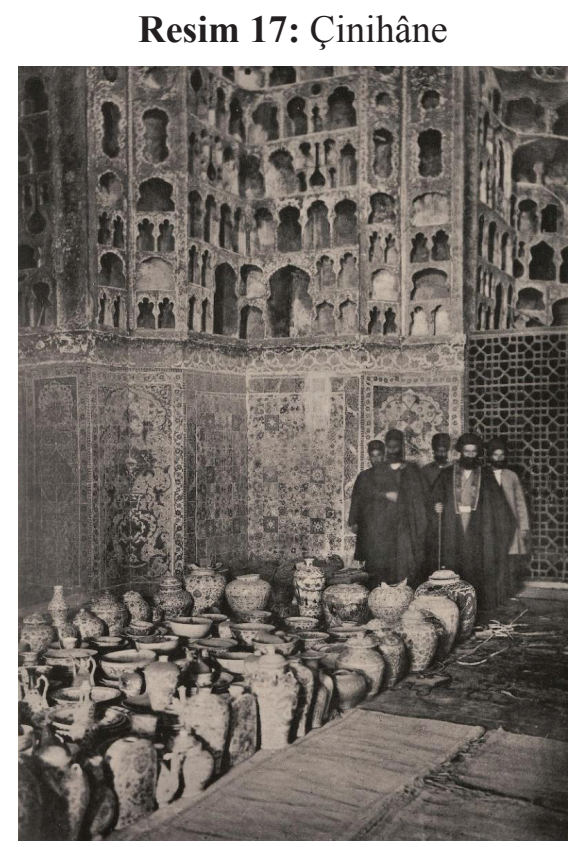

Kaynak: Friedrich, Sarre ed., Denkmäler Persischer Baukunst: Geschichtliche Untersuchung und Aufnahme Muhammedanischer Backsteinbauten in Vorderasien und Persien (Tafelband.) Berlin: Wasmuth, 1901, 32.

Resim 18: Çinihâne'nin merkezi kubbesi içten

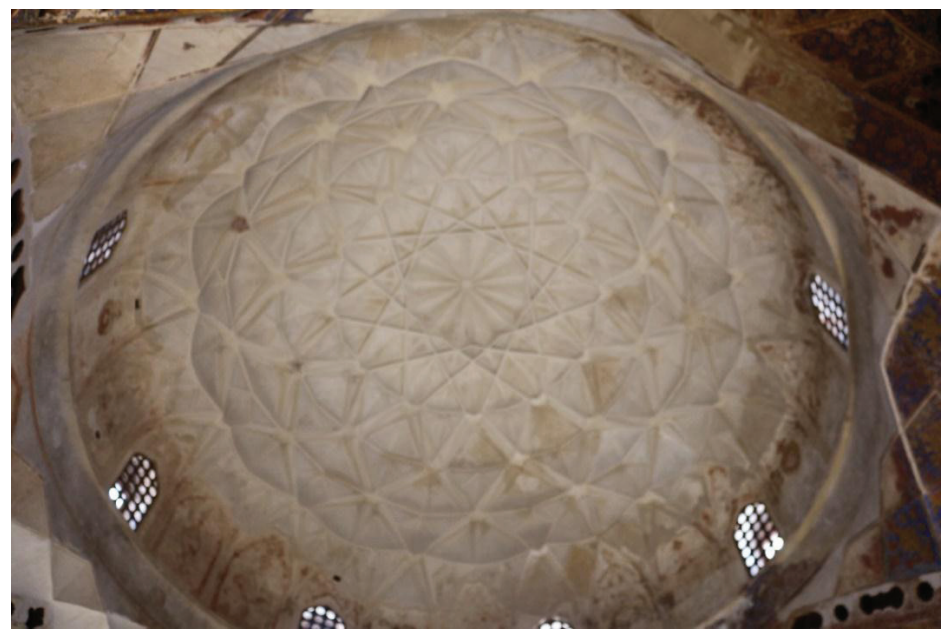


Resim 19: Çinihâne ve Cennetsaray diştan

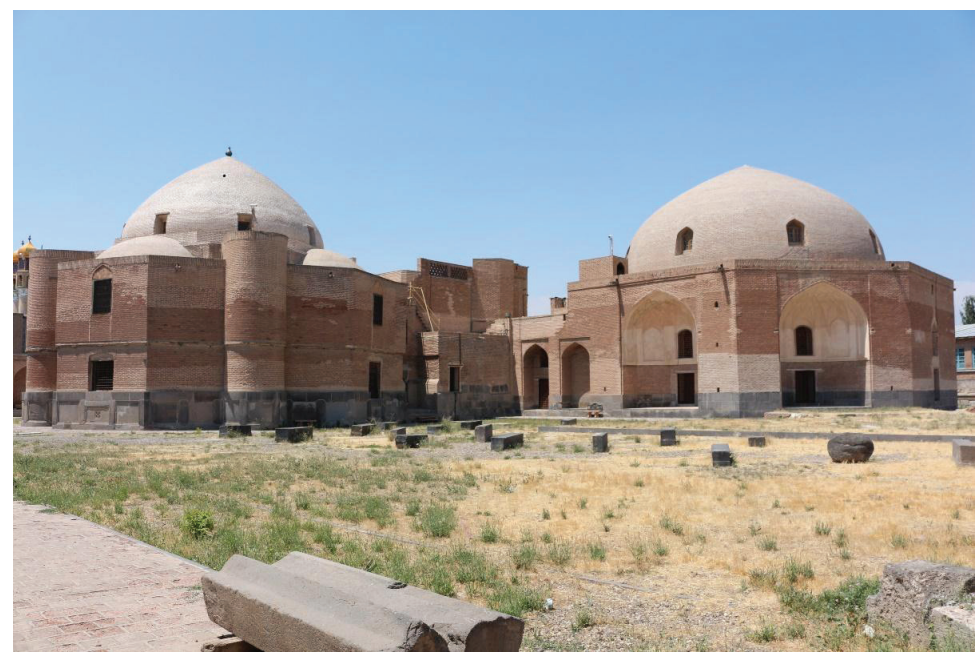

Resim 20: Isfahan Âli Kapı Sarayı müzik salonu

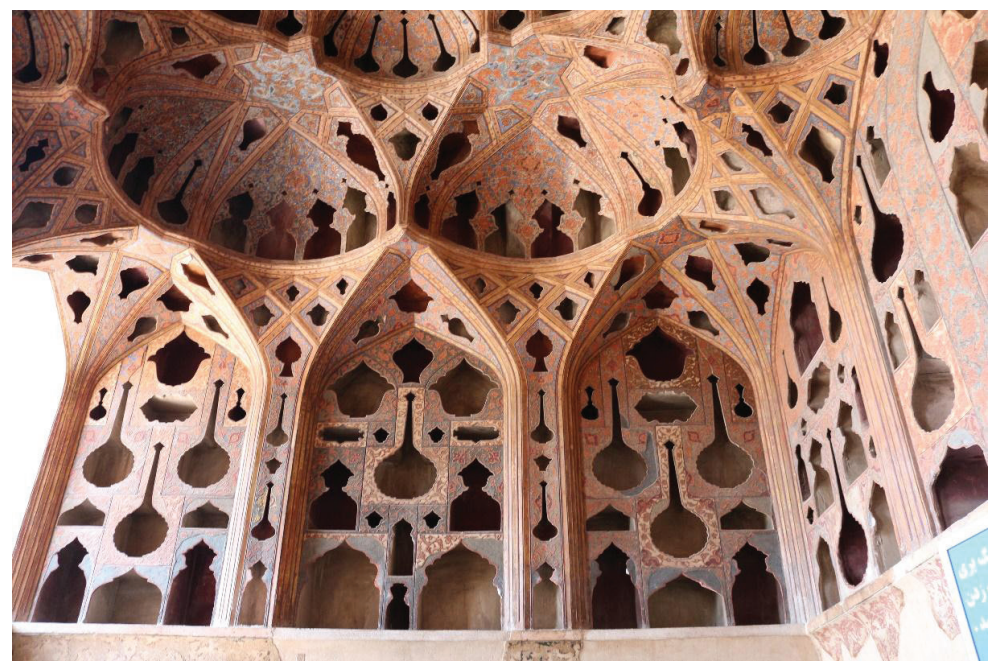


Resim 21: Çinihâne'den çini tabak örnekleri

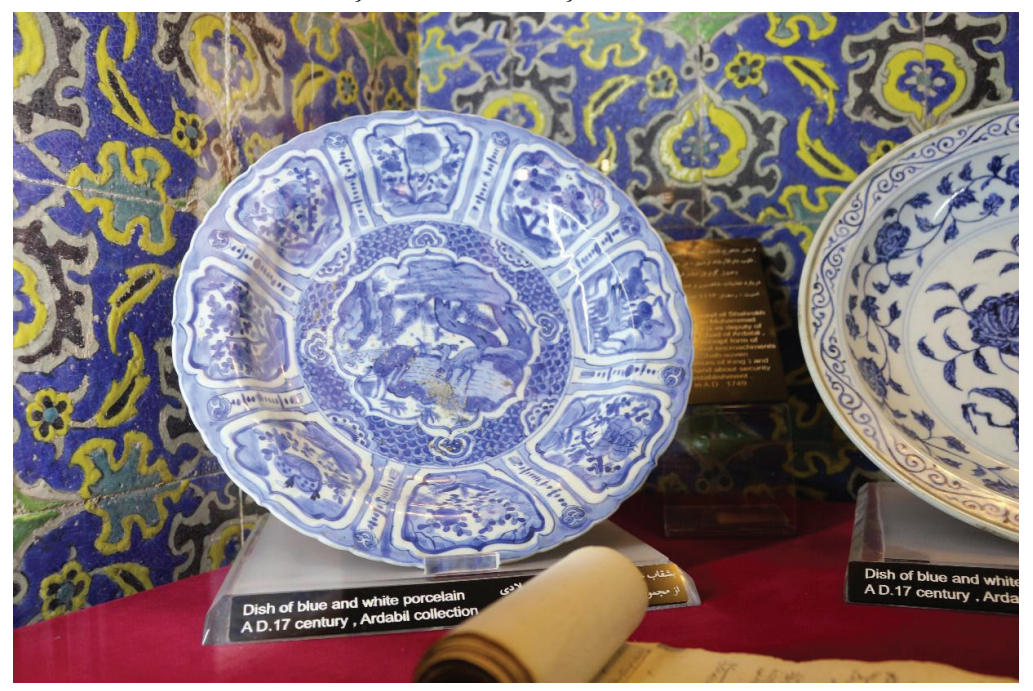

Resim 22: Cennetsaray ön cephe

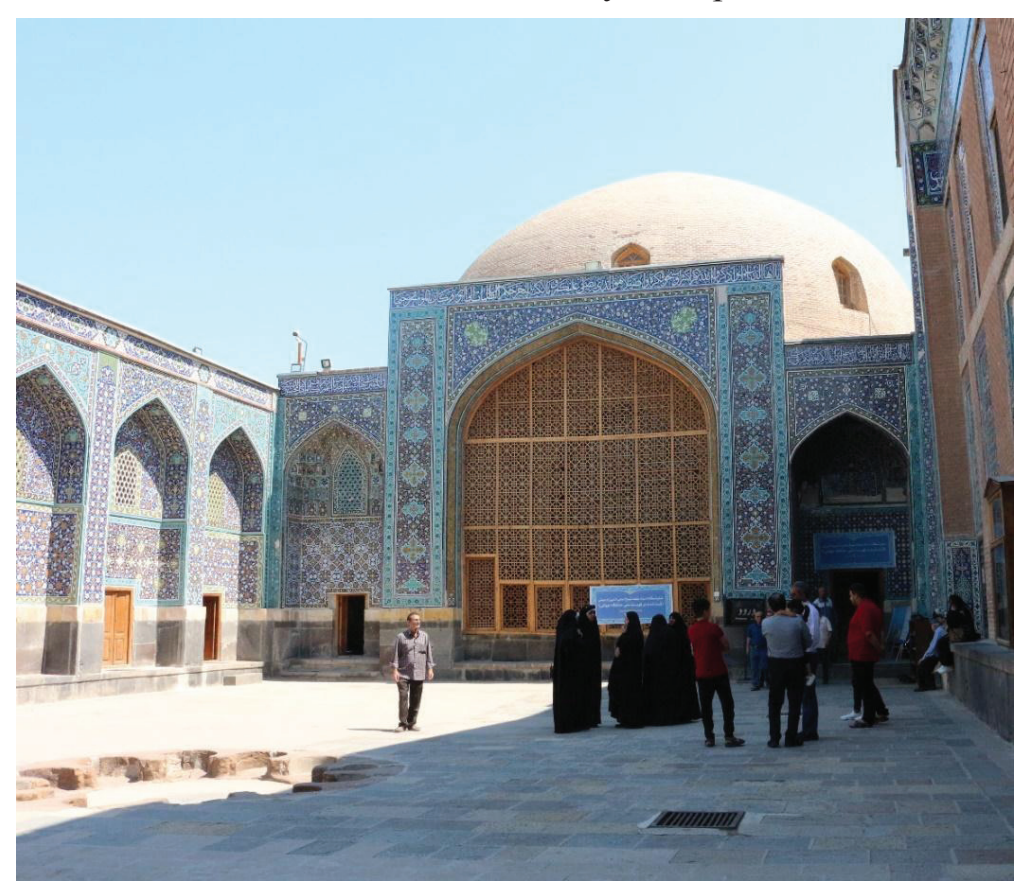


Resim 23: Cennetsaray içten

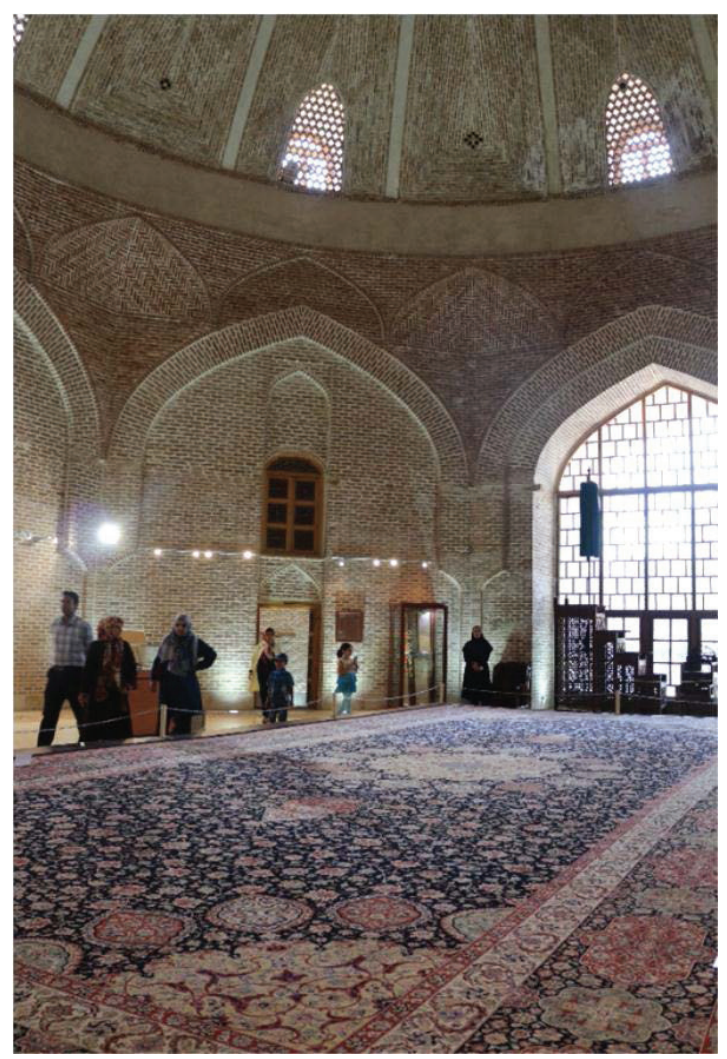

Resim 24 a: Çilehane

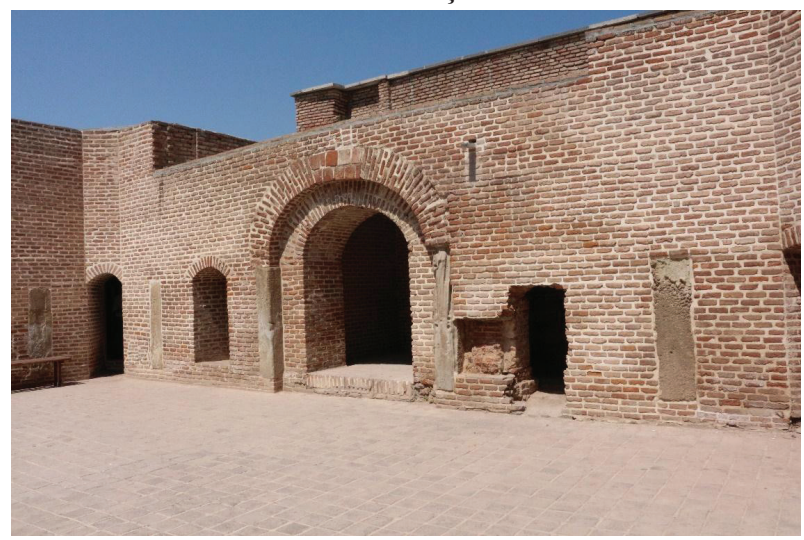




\section{Resim 24 b: Çilehane}

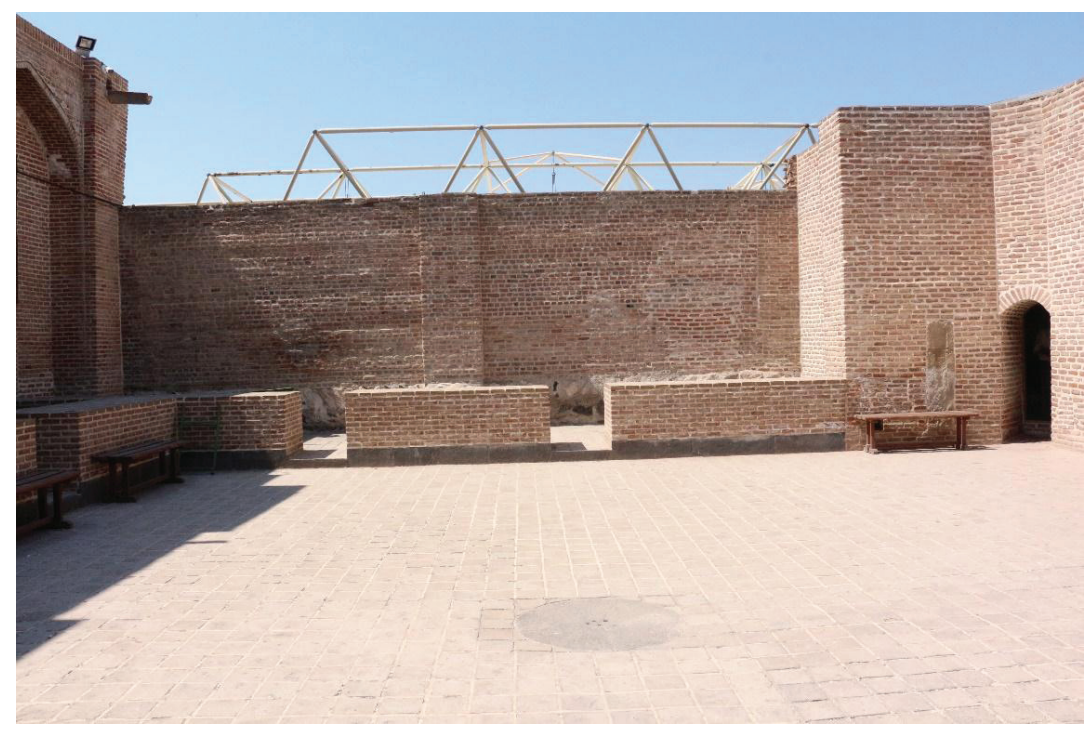

Resim 25: Dârülhadis ön cephe

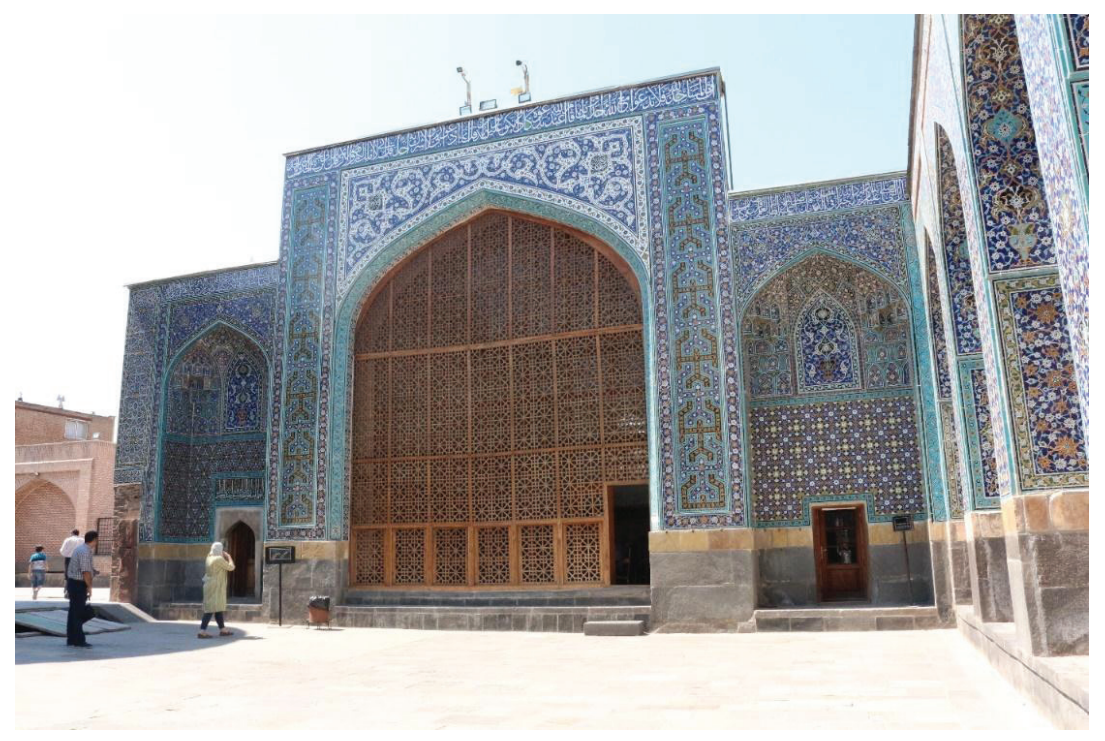


Resim 26: Kuzeydoğu köşeden Şehidgâh

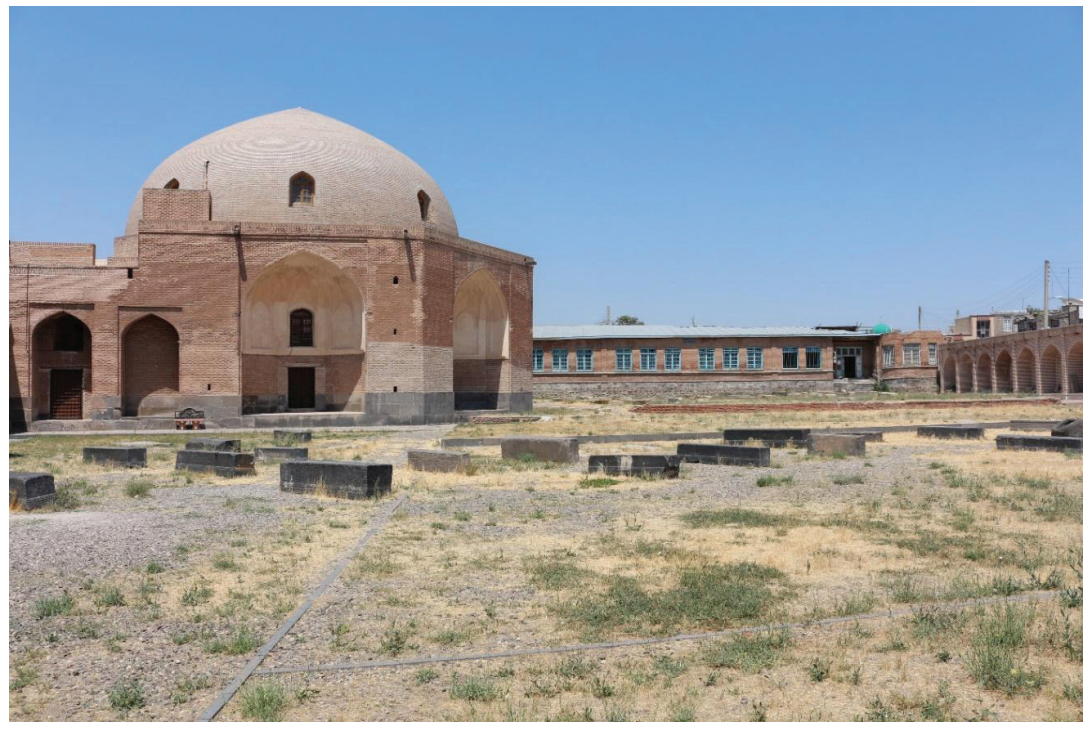

Resim 27: Şehidgâh'1n 1800'lerin sonundaki görünümü

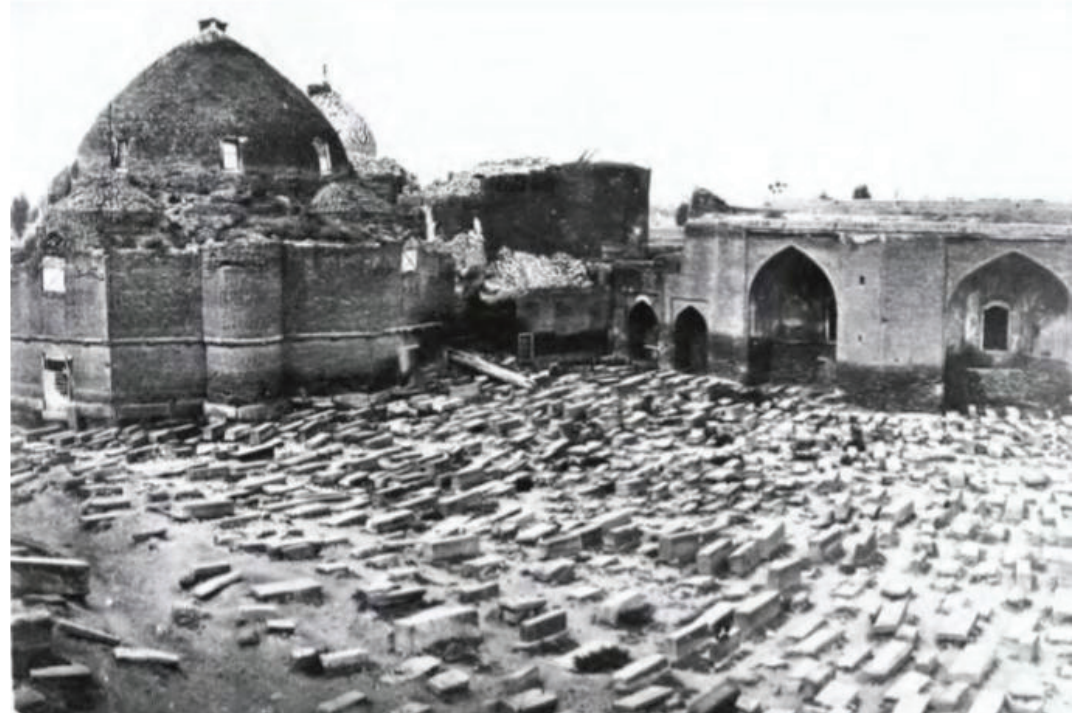

Kaynak: J. de Morgan, Mission scientifique en Perse. Tome troisième. Parties II à IV, Etudes géologiques. Paléontologie I, Paris, 1895, plate 34. 
Resim 28: Şehidgâh'tan bir mezar taşı örneği

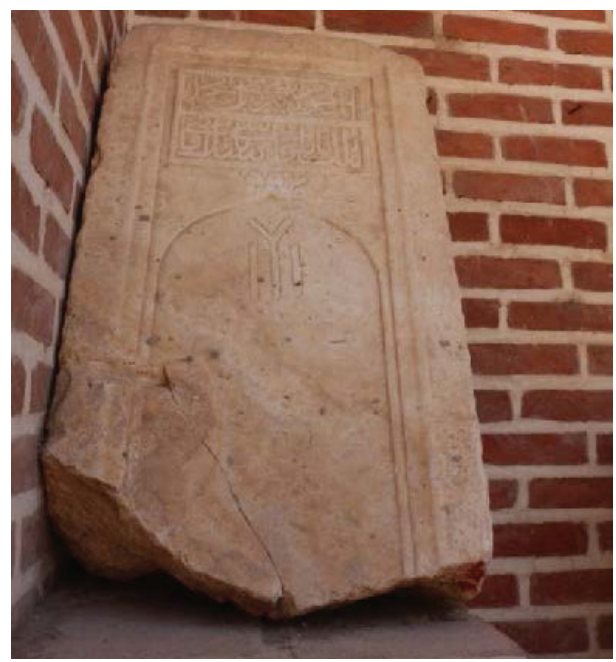

(Şehidgahta Çaldıran Savaşı’nda şehit olanlar için dikilen mezar taşlarından bazılarında Kayı Boyuna ait simge bulunur.)

Resim 29: 1800’lerin sonlarında Âli Kap1 portalinin görünüşü

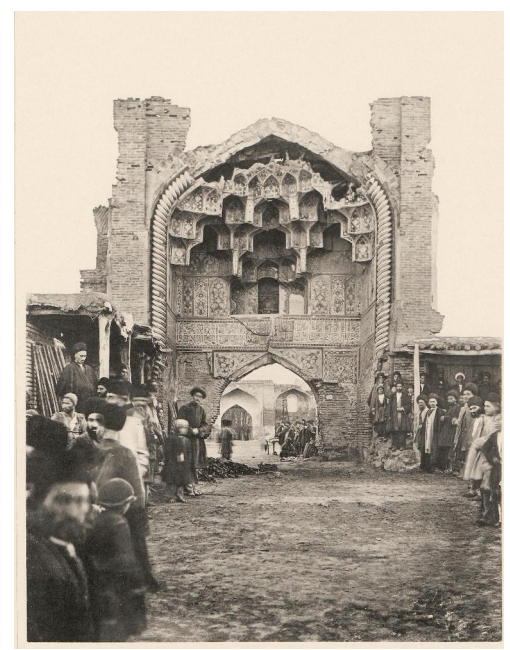

Kaynak: Friedrich, Sarre ed., Denkmäler Persischer Baukunst: Geschichtliche Untersuchung und Aufnahme Muhammedanischer Backsteinbauten in Vorderasien und Persien (Tafelband). Berlin: Wasmuth, 1901, 77. 
Resim 30: Şerbethane'nin kazılarda ortaya çıkan kısmı

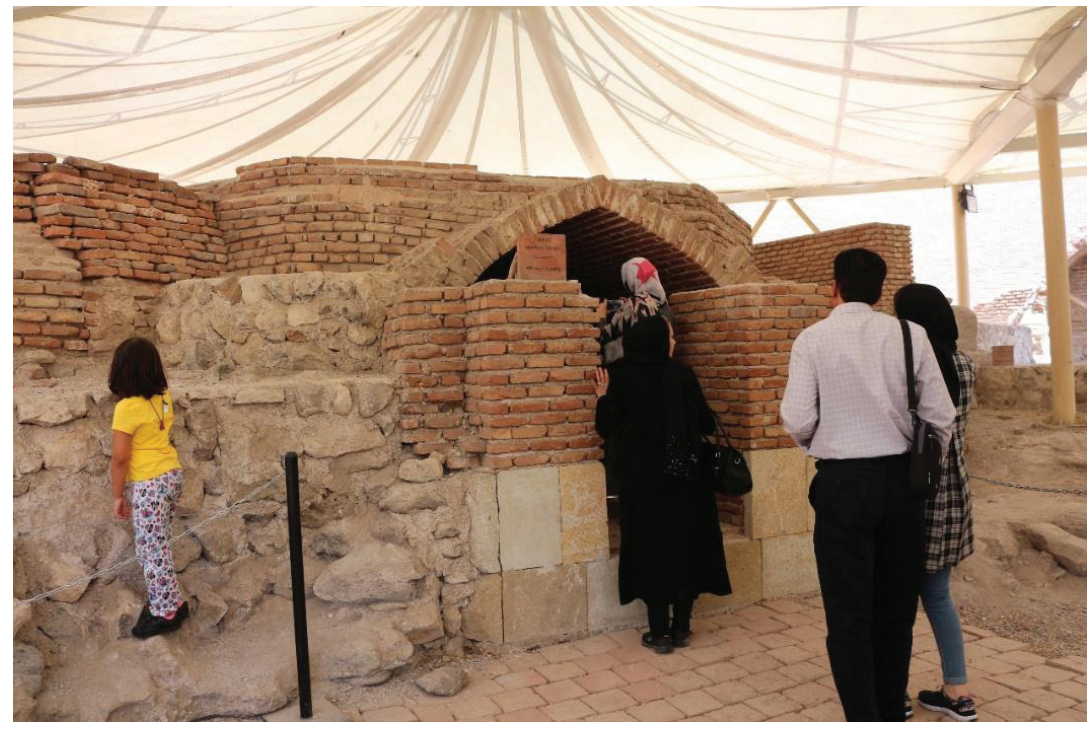

Resim 31: Şeyh Safiyyüddîn'in kazılarda ortaya çıkan evi

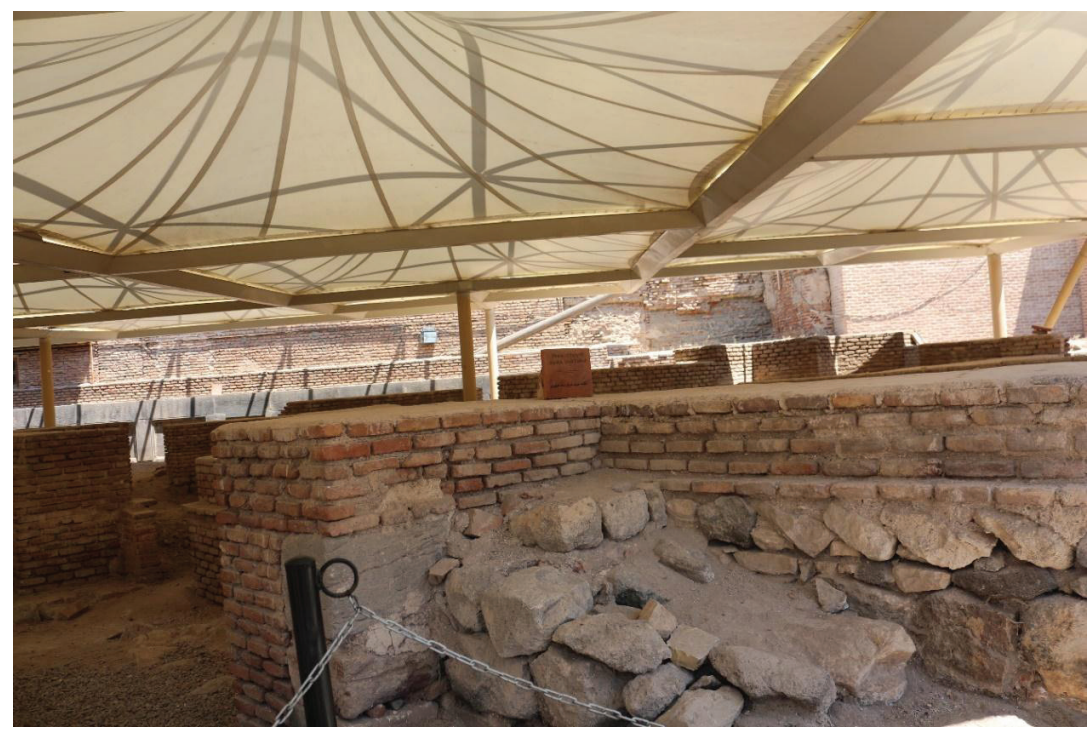




\section{Teşekkür}

Bu makale çalışması için yaptığım Erdebil ziyaretimde desteğini gördüğüm İran Tebriz eski Başkonsolosu Sayın Hüseyin Güngör'e ve Mohaghegh Ardabili Üniversitesi'nden Sayın Dr. Hasan Asadi'ye teşekkürlerimi sunarim. 